\title{
Guide on how to adapt air transport to international transport of passengers in the time of COVID-19.
}

\author{
Dr Zygmunt Dudzicz
}

\author{
DOI: 10.29322/IJSRP.10.07.2020.p10326 \\ http://dx.doi.org/10.29322/IJSRP.10.07.2020.p10326
}

\begin{abstract}
The article presents the current state of knowledge about the SARS-CoV-2 virus and COVID-19 disease in such a way as to provide the basis for the modernization of the flight and airport management system in such a way as to maximally protect passengers and crew from infection and transport of sick people from one country to another. To this end, a method of organizational flight preparation, methods of diagnosing passengers, methods of securing passengers in the field of distance by means of various several different personal protective equipment was developed in order to limit contacts of neighboring passengers in terms of time of exposure to the virus. Several methods of passenger protection and isolation on board were presented for simultaneous use. Innovative measuring and control equipment, personal protective equipment and test methods before, during and after the flight were presented, and practical solutions in crisis situations were proposed. The article contains the state of research and a practical guide on how to accomplish subsequent tasks to achieve flight goals in terms of COVID-19 safety.
\end{abstract}

Index Terms- SARS-CoV-2, COVID-19, physical and medical properties of the virus, methods of infection, mandatory distance, mandatory masks, passenger isolation, virus transport, testing methods, RT-PCR, screening tests, serological tests, cassette tests, aerosol particle size distribution, symptomatic infections, asymptomatic infections, COVID-19 health card, infection by asymptomatic patients, flight organization, compulsory passenger tests, mass infections, lockdown, quarantine.

\section{INTRODUCTION}

$\mathrm{I}$ $\mathrm{n}$ accordance with the principles of good teaching and learning, both sentences "Repetitio est mater studi" (repetition is the mother of knowledge) and "Simplicitas est mater scientiam" (simplicity is the mother of science) are present in this article, so it is not surprising, that sentences on the same subject, written in a different context, also supported by other footnotes, appear for the first time in the descriptive part and then in the next sections of the practical guide. Understanding the essence of the virus and creating a shortened distance requires this method of description, because the virus is new, completely unknown, and the result is the death and unnecessary illness of thousands of people.

The presented article has to meet two functions, to convey the current state of scientific knowledge, practical knowledge, knowledge of the author's literature research necessary to learn about the SARS-CoV-2 virus in such a way that it is possible to protect passengers from infection and the second goal for aircraft and airline manufacturers, airports so that they could prepare organizationally, medically to implement effective substitute distance and secure flight conditions, so as not to carry mass infected people from country to country. Because the article discusses each fragment of the text in great detail, which can be checked in the literature, the more so because the given links refer to a dozen or so different articles that you can read more thoroughly. The more we know about the virus, the better our chances are to protect ourselves against the disease. The big problem is the fact that the majority of web-based messages were created so, that the authors receive remuneration every day, and not to provide reliable knowledge, which is why a critical assessment of the Internet materials that was made in this article is needed. The article deals primarily with aviation, but its conclusions can be applied to all forms of gathering people on the streets, in stadiums, in schools, in the halls, but also at home in the family. Article is written in a simple form to be understandable to all people, regardless of education and occupation. This article will fulfill its purpose, if it reduces the number of deaths and the number of people infected with COVID-19 disease.

The restoration of passenger air transport is one of the most important tasks to restore the state of the economy, as far as possible, to the previous state, as close as possible to the state before the pandemic. Air transport is one of the most important sectors of the economy, hence its restoration is a priority. However, one has to accept the fact that air transport must be adapted to completely new conditions. The previous state cannot be reproduced due to the SARS-CoV-2 virus and the tight closing of state borders in fear of a pandemic. It is necessary to organize air transport so that the epidemiological status due to the SARSCoV-2 virus and COVID-19 disease of the composition of people embarking on the plane was identical after delivery to the destination airport. If during the flight there is a change in the epidemiological status of passengers and crew, it is necessary to immediately detect infected people, their isolation from the rest of the passengers and separate service at the destination port. This does not have to be caused by carrier and crew errors, and may be due to the specific properties of the very high infectivity of this virus. This virus is a great unknown to us but a very negative unknown, and in order to avoid its harmful activity, we must act very strictly. We need to be aware that in adverse circumstances one sick person, even asymptomatic, can infect a hundred or more people during a flight of several hours. Countries that have mastered a pandemic, are very careful that there are no outbreaks in their area and therefore have introduced very strict controls on arriving people to protect themselves against the arrival of infected people. In China, during the last month of April 15-15 May, not a single person died of COVID-19 disease. Despite this, small 
individual outbreaks of plague break out, even a dozen or so infected, then the cities are closed and infected people are caught until the last person. Let's imagine that if one plane brings 300 infected people to Wuhan, Milan or New York, without their control and catching the sick at the airport, they will spread peacefully all over the country, we wait quietly a month or two, then the state of epidemic can no longer be master. After controlling the pandemic, after completely suppressing it, it is necessary to constantly maintain the state of readiness to fight the virus causing the disease and strictly control people entering the country. When we have a population of 1.4 billion people, any mistake can turn into a tragedy. Countries that have already fought the MERS and SARS-CoV-1 viruses were better prepared to fight the SARS-CoV-2 virus. It is necessary to use the experience of these countries from South Asia, because sometimes it is enough to successfully adopt their methods. SARS-CoV-1 and SARSCoV-2 viruses have $85 \%$ identical genome, but completely different infectivity. The main thing is that for the human body, this virus is completely new, that is, man is vulnerable to its action. SARS-CoV-2 virus and its subsequent mutations and subsequent types of viruses even more contagious than this, may appear even several times a year or every few years. The more that the list of viruses that can cause epidemics is quite long, most of these diseases we can not treat effectively, we only treat symptomatically, as there are no medicines or vaccines for them. We have to be prepared for the worst. Every day, around 2,290 people die at dawn on COVID-19, about 22,836 people for all infectious diseases, about 857 people for seasonal flu, about 1,732 people for cancer, and about 2,677 for AIDS. It is therefore necessary to increase public hygiene from the constant habit of washing hands. But it is also necessary to increase epidemiological safety during air transport, for which aircraft manufacturers and airlines will be responsible. The point is that during the flight the passenger does not received illness as a gift or pass it on to other fellow passengers. The Chinese National Health Committee announced on May 11 that only 14 new infections were reported, including 11 in the city of Shulan, which were immediately blocked [1]. Only one case was found in Wuhan, but it was enough to issue an order, test the entire 11 million Wuhan residents for 10 days. To my knowledge, there is no country in the world where 14 infectious hospitals were built from the beginning in 14 days, or 11 million people were tested in 10 days. The state of scientific research on the virus and COVID-19 is the most advanced in China, because they have a large database for comparative studies [2]. The evidence that China has completely mastered the pandemic is the information that they are already dismantling last 14 infectious hospital in Wuhan, because they no longer need it. We are not fully aware of the virus's ability to mass infect people, in the absence of adequate distance between people and the occurrence of exposure to this virus from a few hours to several minutes, which also results from my literature research. In the office and residential tower in Seoul, 18 floors, 216 people worked on the 11th floor together, including 94 infected with COVID-19, which means the virus incidence rate was $43.5 \%$. The success of the Korean authorities' response strategy to the virus resulted from mass testing, contact tracking and the use of digital surveillance tools. There are no restrictions on the movement of residents in Korea. This study shows how easily SARS-CoV-2 virus travels from one person to another [3]. After controlling the pandemic in Korea again on May 2, 2020, according to the Korean Control Center, the plague returned in Daegu, over 100 people infected by one 29-year-old man who visited gay clubs and bars in city Itaewon shopping and entertainment district in Seoul [4]. The arrangement of people in the call center and on the plane is quite similar. As shown by my analysis of published literature, the possibility of infection depends on the amount of virus and the time it is exposed. There must be a virus, i.e. the right amount of it, and it must affect the person for a longer period, in the analyzed cases from half an hour to 8 hours. We must avoid contact with the virus and reduce the maximum exposure time, i.e. the impact of the virus on humans. The above study was based on the generalization of many research results and experience of teams, proposes practical solutions adapted to the conditions we have on the plane. To implement effective international air transport, it is still necessary to meet stringent passenger control requirements applicable to arrivals in China, Hong Kong, South Korea, Taiwan, Japan and Singapore and other countries. We do not yet know the conditions of transport to most countries, e.g. USA, Canada, Australia, which are still closed. It should be remembered that these rules are changed by these countries flexibly, depending on the current epidemiological situation. You must have the consent of two countries to fly and meet all their requirements for COVID-19. Currently, for example, Raynar operates only $1 \%$ of flights from the prepandemic schedule.

Passenger transport almost froze, decreased by $90 \%$ compared to pre-virus times. Air traffic due to lockdown and closing of borders almost completely froze. As stated in the press about the proposals for the use of Airbus A380 and Boeing 747 aircraft belonging to British Airways, which can be used as temporary intensive care units in the fight against a coronavirus pandemic, according to The Times, I think that was probably not such was the purpose of their design and building. Also, the "Caircraft Project" as a joint idea of a group of leaders and experts from the aviation, medical and technological industries, i.e. the conversion of a Berlin airport into a huge hospital has similar characteristics. The idea has already received the support of the Civil Aviation Authority and is now waiting for the government's approval of this idea [5]. The modern and gigantic Berlin Brandenburg airport, which is being built in Berlin, was to be one of the best in the world and is to turn into a giant flat hospital. It's probably another idea type of science fiction. Airport change with an area of 220 thousand $\mathrm{m}^{2}$ on "Covid-19 Superhospital BER in a situation where Germany is dealing with COVID-19 disease very well, taking into account their economic and population potential is probably a bad idea [6, 7]. Maybe it is better to try to adapt most of the planes to transport people during a pandemic, in such a way as not to transmit plague foci from one country to another with people, because this is probably a better solution. The more that in my opinion, the adaptation of existing large aircraft, it is possible to transport ordinary passengers after modification, and as needed, to transport sick people from one country to another for treatment, to transport tourists to resorts and holiday resorts.

Due to the fact that I carry out literature research on SARSCoV-2 and COVID-19 disease, I have become acquainted with them thoroughly and with its properties for infection and masking. The RNA virus defies a simple classification of the living body 
and the dead body because it is physically and biologically present in these two conditions. This virus requires a host to be human or animal to cause infection, otherwise its infectious nature will not be revealed. This virus, ejected from the body of an infected person, has unprecedented ability to survive beyond the host, until it is effectively killed, rendered harmless, and successfully disinfected. You do not need to use a weapon to kill him or deactivate it; thoroughly wash your hands with soap and water, disinfect any surface where it can be, warm it with lighter fire, iron, dryer, microwave or washing things at $60^{\circ} \mathrm{C}$. I have prepared thorough literature research in this area, presenting research from many centers, scientists and physicians practitioners. In the context of this, I became acquainted with China's efforts to overcome this pandemic for a population of about 60 million people and other countries also, which have significant successes in overcoming the pandemic, as; Hong Kong, South Korea, Taiwan, Japan, Singapore, Thailand. Based on the course of the COVID-19 pandemic and its fight, ruthlessly using all possible means, in China it was controlled and suppressed. In China, the state's struggle against the virus lasted from January 24, the blockade day of the Huabei province until March 15, 2020. The total blockade of 11 million Wuhan ended after 76 days. Articles describing how coronavirus has become Chinese Chernobyl, are also mobilizing the Chinese authorities to be constantly ready to fight the virus $[8,9,10]$. Despite the end of the pandemic in China, there is a constant fight against local outbreaks. Fear and terror are also generated by the media, press and the Internet. There is constant fear of a pandemic recurrence that 100 million Chinese may be waiting for repetition of blockades and restrictions. All services in China are ready to immediately combat the pandemic $[1$,

2 ,

$11]$.

The highly developed countries of the EU and the US mistakenly thought that China is far away and that it does not concern them. Instead of taking the time to prepare for a pandemic in their own countries, a pandemic was underestimated. The development of a pandemic in Italy, Spain, France was caused by several months of delay caused by its hidden development of the disease. As the pandemic landed in Europe and the US, pale fear fell upon governments. The only reaction always delayed by several months was panic, closing schools, of trade and the entire economy on a massive scale. Blocking people in apartments, lockdown has been going on for 3-4 months and the end cannot be seen. The later we take on radical solutions in a form such as was done in China, South Korea, Taiwan, and Japan, the longer the pandemic will be indefinitely. If we got to it too late, ineptly, it may take years and the SARS-CoV-2 virus will stay with us permanently. Of course, the pandemic will also expire without doing anything, such is its nature, as there are no candidates for further infection because everyone were already sick. On TOK FM radio, Professor Johan Giesecke, adviser to the Swedish Public Health Agency and WHO, criticized the so-called lockdown in Europe. "These were political and not scientific decisions, including a lot of unnecessary ones," he said in an interview. According to Giesecke, it is not yet fully clear whether COVID-19 treatment gives virus resistance, whether this resistance is permanent and whether it affects everyone. He said the very important sentence "If COVID-19 immunity does not provide immunity, we have no chance to create a vaccine," he emphasized. According to a WHO report, 70 teams are working on a COVID-19 vaccine [12]. What connects the coronovirus from Wuhan and SARS is that there is no effective vaccination against both viruses and 17 years have passed since the SARS pandemic, which unfortunately, in my opinion, bodes badly for opportunities to develop an effective vaccine [59]. The key to understanding the principle of SARS-CoV-2 coronavirus causing COVID-19 disease, the course of this disease in several different stages, the limited possibilities of testing the state of the disease by RT PCR and serological tests is the following text of the instruction of the PCR automaton. The instructions for the Xpert @Xpress SARS-CoV-2 PCR testing machine state clearly warns that: "A negative result does not mean the absence of SARS-CoV-2 infection and should not be the only basis for treatment or other decisions related to patient care. .... Positive results indicate the presence of SARS-CoV-2 RNA. Positive results do not exclude bacterial infection or superinfection with other viruses. The pathogen detected may not be the definitive cause of the disease. ". pp. 1 [60]. The research presented in the article is to help understand this text above, understand the essence and methods of the virus, its transport in the air, stages of the course of the disease and why you should follow the instructions described in this the article to recreate passenger aviation.

\section{Suspicion of depriving citizens of citizens' rights}

At the current stage of the pandemic and legal status of states, i.e. the state of total chaos and ad hoc action of states, in order to effectively launch air passenger transport, it is necessary to temporarily, partially limit the citizens' rights of passengers, preferably with their written conditional consent, with a note ("for the purposes of COVID -19 ") with the possibility of an appeal to court. The second method is to abuse the right to privacy of citizens by using a state of emergency or by using an announcement of the state of epidemic disaster.

There is always a suspicion that the collected personal data of citizens for the purposes of COVID-19 will be used to deprive citizens of citizenship rights, to track citizens for political purposes. No declarations by politicians or officers are worth anything, since lying, deception, lack of responsibility are a common norm for most politicians. The American magazine "Vice" included also 30 worst countries in its classification. Unfortunately with Poland, this is not a reason to be proud. We found ourselves in a group of countries that are using a coronavirus pandemic to increase repression against their citizens and to carry out suspicious corrupt purchases. Special laws have been passed on impunity for politicians for violations of law and fraud during pandemic service, of course, everything for the benefit of citizens, so that corruption activities would be under special protection [47].

This problem will not be solved without introducing criminal and financial liability for politicians and officers for unauthorized disclosure of data located in state institutions, or corruption scandals when purchasing protection measures. Even a database of people with COVID-19, a passenger list may be subject to illegal trade. Only the introduction of criminal liability of officers and politicians, with simultaneous strict institutional control of citizens, guarantees the security of the citizens concerned. The solutions given in this study are a temporary prosthesis used to reconcile security conditions and standards of data use in Asian 
countries and Europe, where they are completely different. Depending on the country, different forms of citizen data availability are used and should be adapted periodically or with the consent of citizens to fight a pandemic. In South Korea, Taiwan, which are currently democratic, there is supposedly a citizen's trust in the state in terms of consent to share his personal data, contact details, telephone data for treatment purposes, which is guaranteed by the procedures operated by the state, but it is a myth that prevails in Europe, because there the law is already adapted to fight the virus. After the MERS epidemic in 2015, a provision was introduced in Korea that in such situations allows to ignore strict privacy protection principles [4]. In most cases of these countries, the state covers all medical costs, quarantine costs, and testing costs, and fully protects personal protective equipment, its distribution and support protection against speculation. The state permanently provides full knowledge to the public about the need to share and how to use this data. This citizen's trust in the state is also a myth, because in Taiwan the disease was included in the highest infectious category. Thanks to this, people with infection symptoms could be forced to quarantine, mass production of masks with the participation of the army was launched. The Epidemiological Management Center organized daily press conferences, with an accurate presentation of the status of the epidemic, and coordinated the fight against the pandemic. People with a history of respiratory failure who did not have the flu were tested for the presence of other SARS-CoV-2, SARS and MERS viruses. For this purpose, location tracking of mobile phones, QR codes, airport control with full computerization, artificial intelligence and all kinds of cameras were used [13, 14, 15].

In European countries, such responsible mechanisms on the part of the state and citizens do not function, because they have not been worked out, and the European Union during the pandemic failed completely as a body uniting nation-states. Every EU country was left entirely to their fate, at a time when Italy and Spain needed and asked for help, were abandoned to fight the pandemic alone, and a few months earlier they incurred the greatest costs, of wild migration created at the EU's request, because it did not solve any problem, and now migrants are fleeing from Europe, back to Africa and Asia. For example, Korea after the MERS respiratory failure epidemic in 2015 introduced a provision that gives authorities the right to ignore the protection principle in the event of an epidemic threat. privacy $[16,4]$. What prevents such a statutory provision from applying in other countries? This would allow for the development of strategies for precise testing and aggressive reproduction of the contact chain of infected people who have little contact with other people who are identified as to where to stayed. Every citizen is required to install a government tracking application that works in the wanted geolocation system. The first maps of infected and quarantined locations in Korea were developed by amateur IT specialists who gave them to the state and they were further expanded and integrated with databases of state. The Korean strategy is based on tracking people, revealing infected locations on the map, mass testing and treatment. This system was implements, as Hyelim Lee reports, disclosing on the map the place of residence of infected people, date of infection, people in quarantine, sending alerts and warnings to people residing in the area, which greatly facilitates the search for sick and suspected people [17, 18] . A similar system of infected people, their location and infected contacts operates in Taiwan, coordinated by the rapidly created Central Epidemiological Command Center. Instant reflexes of the authorities prevented the virus from even spreading, because the control tests were started on December 31, 2019, as it was in Vietnam, thanks to which schools closed for only two weeks. These countries; China, Taiwan, Vietnam, South Korea emerged victorious from a pandemic. Pandemic is important for the existence of the whole society, hence the public interest in virus protection has become more important than violating the basic privacy standards of infected

people

$[14$,

$15]$.

\section{Impact of SARS-CoV-2 virus on the blocking of economic activity by governments.}

In the fight against SARS-CoV-2 coronavirus, it is only the efficient actions of governments that decide, and no medical reasons. Efficient management of the state includes management in times of war, natural disasters and a pandemic. It depends only on the efficiency of the state authorities at what time and at what cost the pandemic will be overcome. Medical considerations are well known and are limited to mass testing and symptomatic treatment in hospital or referring the patient to quarantine. The virus is only much more contagious than those previously known to us viruses and it is completely new to us, which means that it has virtually no research. On the other hand, the organization of infectious hospitals, material supply, searching for the sick and people contacting the sick, organizing mass testing of the population is the task of the state and its ministries or appointed government bodies. The state is obliged to ensure places in infectious hospitals, doctors and medical staff equipped with personal protective equipment, personal protective equipment for citizens, medicines and cleaning products for all citizens as well as an efficient COVID-19 disease testing system. The state is obliged to immediately order and enforce the obligation to distance with a very clear explanation to the public why it does it, how long it will last, what will be the costs - if we do not do it as soon as its possible. All restrictions on civil liberties, the obligation to remain in quarantine at home, movement restrictions must be guaranteed during which period they apply and the restrictions introduced will be canceled after the pandemic, which should be guaranteed by law. A team of specialists for crisis management, persons known by name and qualification should be appointed to help the Minister of Health and the Prime Minister. They determine the effectiveness: quick identification of a zero patient, immediate introduction of strict lockdown for a month, two, strict social distance, testing infected with COVID-19 and searching for contacts of infected people. Even stopping the entire industry for a month or even two is possible if the state of the pandemic requires it and the state cannot control the pandemic without stopping everything. States and governments are guilty of stopping all economic activities, including airlines, since they have stopped them, they should now pay damages or subsidies, or relieve the tax burden. Swapping airports for hospitals and planes for ICUs, exchanging planes for respirator rooms are probably ghostly and bad ideas. As it results from the activities of several countries, a lockdown is needed, but for a period of one month, up to two, the time necessary to prepare the state organs for effective 
fight against a pandemic. The most important tool of the state is to master digital IT surveillance tools including tracking patients and their contacts, and the use of owned databases for COVID-19 purposes, because only this allows you to limit the lockdown time for industry, trade and services. Nobody predicted that politicians would destroy the economy so easily and be completely unpunished, as we can see in some countries. China is a different scale of the problem, due to its urbanization and population potential, and the fact that it was the first country affected. By contrast, countries such as; South Korea, Taiwan, Singapore, Japan did not stop the economy and trade, they defeated SARSCoV-2 without stopping the economy and trade. These countries, after mastering the pandemic at home in an exemplary manner quickly received a ricochet attack from countries that were unable to fight COVID-19 within at least 2 months, i.e. mainly EU and US countries. These countries closed their borders too late, they did not introduce an immediate strictly enforced rule of distancing, staying forced at home, i.e. lockdown and stopping industry, trade in services, education, instead of preparing to fight the SARSCoV-2 virus. We received a new version of the Iron Curtain from politicians in all developed countries, but without the possibility of raising it. The basis of the state's activity is to support and develop industry and trade, not its mindless destruction.

\section{Methods of collecting swabs called "drive-thru" and "walk- thru" and performing tests for passengers useful at airports}

Test methods for SARS-CoV-2 virus and COVID-19 disease state require collection from a suspected swab to be taken and tests performed. Methods developed in South Korea "Drive-thru" [45] and walk-thru $[46,18]$ are suitable for direct use at airports as part of the organization of the flight. Within the organization of the flight, persons who should have tests, type of tests and the method of collecting swabs for testing will be selected. At the airport, swabs are prepared and tests are carried out immediately. Passengers arrive at the airport check-in in advance and samples for testing, can be taken in the car of the passenger who drives to the appropriate position, as he arrived by car or samples are taken for testing at the pedestrian stand. Therefore, both methods are discussed in more detail below. The download stand can be prepared in the form of a download module, similar to the one set up at the University of Gdańsk in Gdańsk, as shown in Fig. 1. The people appointed for testing will be first verified in the survey and a list of those selected or all, for testing from choosing the type of test will be given to passengers in advance.

In Korea, two methods of swab collection were developed from a person suspected of having COVID-19 disease called "drive-thru" and "walk-thru" depending on whether the subject is passing a car and the swab is taken through the window or the subject comes to the point of collection on foot. In South Korea testing is carried out on a massive scale, hence portable research points and travelling laboratories were established. "Drive-thru" and "walkthru" tests are also extremely popular. In the "drive-thru" method, the patient sits in the car, opens the window, and the diagnostician in a full suit and protective suit, mask, glasses takes a swab, describes and the patient leaves. The advantage of these methods is that employees performing material sampling do not need to disinfect rooms after each test. [19, 20]. There are several variations of these methods as to the very way the swab is taken in a non-contact, with full protection of the diagnostician himself. I discuss this method on the example of the photo shown as Fig. 1, because it has some elements in common with the distance for possible use in an airplane. The picture shows the very moment of taking the swab by the diagnostician, but this picture does not explain this problem. In Poland, the first module of several zonal stands for collecting swabs from pedestrians was launched in Gdańsk. Here we see. that the diagnostician only has a cap, he is only wearing a incomplete cap with a visor shield and has an exposed upper part of the head, although he has a full suit from the neck down and gloves secured with an elastic bandage. This photo requires a detailed description, as it suggests that we can equip our passenger in the plane with such a cap with a plastic cover, a mask and he will have full protection. Only this position in the picture is misleading, because it presents only one section of the selfsufficient test unit module. The module with several sections does not need an external media source, it is equipped with autonomous sanitary facilities, which ensures the safety of medical personnel and the patient. The module design provides several zones and sluices for material collection, has a high quality mechanical ventilation system with a dedicated system of division into negative pressure and overpressure zones with HEPA filters [20]. Now there are only some similarities to the plane, if we solve the distance between the seats, dress the passengers in protective clothing, overalls, masks, such as full caps with covers in the photo, or we use plastic curtains on the joints and the aircraft ventilation system will work under vacuum with a vertical flow direction then we only have a safe system due to COVID-19. The plane has a HEPA filter at the end of the air conditioning system to catch viruses from the air. No individual elements in the form; masks, visor covers, plastic drop-down covers, google, gloves will not protect a person against the virus. You have to use several elements at the same time and still verify them practically on the plane, preferably with a simulation similar to that shown by NHK Japanese TV. The NHK Japanese broadcasting station in cooperation with infectious disease experts from St. Marianna University School of Medicine in Kawasaki showed how coronavirus is transmitted between people. For this purpose, they simulated the behavior of 10 people for 30 minutes in a restaurant during a meal. One of the people simulated an "infected" person because he had fluorescent paint on his hand, as if after coughing in his hand. Then they turned on the UV lamps to check where the fluorescent paint was, which "infected" spread, everyone had it, almost everywhere also on the face [22].

The rule is that passengers buy their own masks, as WizzAir and IATA intends to do, does not solve anything. In domestic internal communication, we can use various simulated protection models, but this will not work in international transport. 


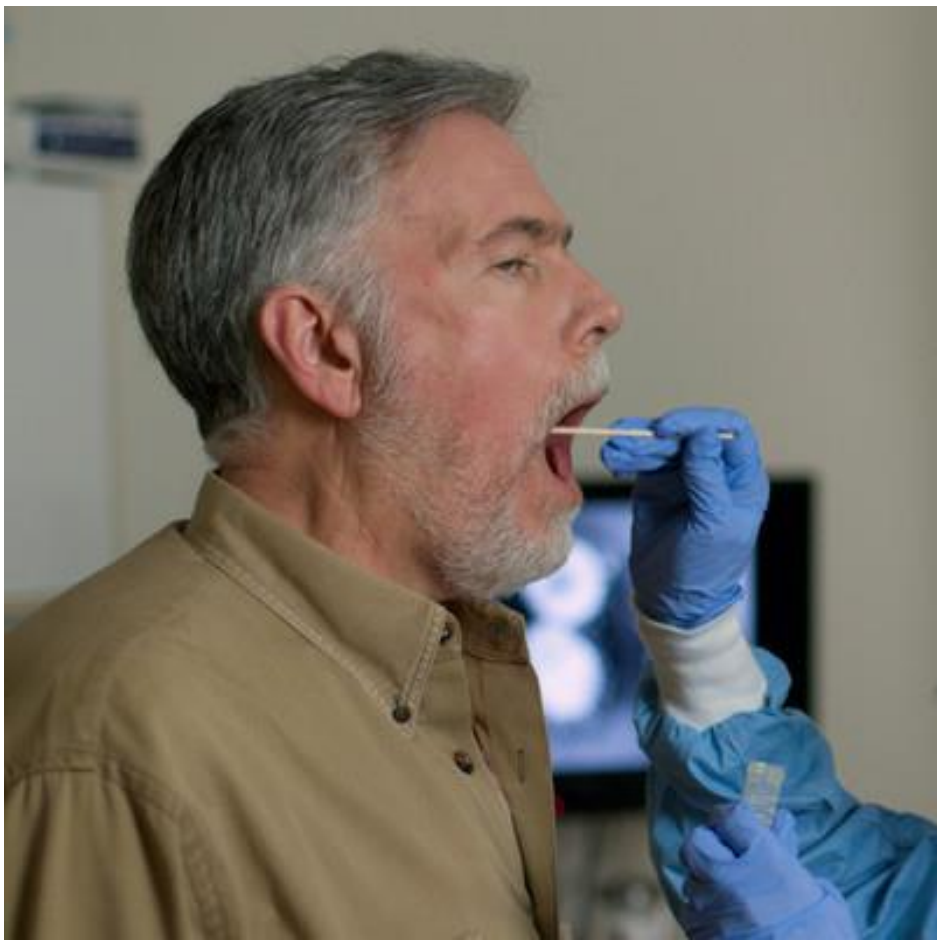

Fig.1. "Walk-thru" stand for swabbing. JHDT Productions / Shutterstock [20]

The redundancy of organizational measures for the preparation of the flight before boarding the passenger, overzealousness in the principle of shortening the distance between passengers and the arrangement of seats in the aircraft, the introduction of sometimes even partially duplicated passenger protection measures will ensure optimal safety obtainable due to COVID-19. Real passenger spacing resulting from experimental research of prof. Lydia Bourouiba of the MIT Massachusetts Institute of Technology, this distance should be 7-8 m. This was proven by experimental research of exhalation cloud images. Whereas, on May 20, 2020, WHO recommended "maintaining at least 1 meter distance between people", which stands in sharp contrast to several other studies of the teams that I found $[23,24$, 25]. Chinese studies prove that the virus travels for $4.5 \mathrm{~m}$ and hangs in the air for 30 min [58]. If, during the flight, there is no additional infection of passengers, even if all the means of control, testing fail and on board there are nevertheless individuals qualified as healthy at the time of boarding who have fallen ill, then following the instructions given we will probably avoid deterioration of the epidemiological status of passengers due to COVID-19. Therefore, during long flights, passengers need to be diagnosed during the flight and when a sick person manifests himself, he should be immediately isolated from the on-board room so that he does not infect others. The greatest progress has been made in recent months in the development of RT PCR molecular genetic tests and even more so in the field of rapid blood serological tests. Special discussion and analysis require tests developed in recent years in Singapore, China, Taiwan, USA and South Korea [60], of which there are several types to be used after checking. Three methods are the basis for effective virus control: identification of patients along with tracking their contacts, quarantine and rigorous distance and tests, tests, tests in accordance with WHO recommendations. Only tests allow you to control and stop the development of infection.

In the case of tests, their verification is necessary because there are a large number of incorrect test results, both positive and negative. Re-verification should be repeated in another laboratory or in the same laboratory, but with a different method. In the case of a very efficient laboratory for testing at airports, the so-called pooling of biological material for screening, in which we expect many people with negative results. This method is also well suited for testing for asymptomatic people, since one test is performed for 10 people, but perfect purity and diagnostic technique are required here [26, 60]. South Korea developed rapid blood serological tests, e.g. GenBody COVID-19 IgM / IgG, of which 6.2 million were exported to 15 countries in March 2020. The test requires 1-2 drops of blood, is 10 minutes, suitable for testing asymptomatic people, gives $96 \%$ accuracy for antibodies. In Korea, 34 companies were authorized to export diagnostic agents and polymerase chain reaction (PCR) equipment, including 19 companies to export reverse transcription PCR kits (RT-PCR) [61, $62]$.

The fastest test results are delivered in China - less than a waiting day in $73 \%$ of cases, and $8 \%$ of doctors receive results within an hour. For example, the Academic Sinica research team in Taiwan has developed a rapid molecular nucleic genetic test that shortens the standard 4-hour test to 15-20 minutes. There has also been the automation of manual performance of RT PCR molecular genetic tests, which are largely performed by automates. For example, the GeneXpert Real Time PCR device for 4, 8, 16 samples performs tests by the American company Cepheid, automatically in 45 minutes. The instruction manual is so trivial that a laboratory technician can handle the operation. We pipette 200 microliters of peripheral blood onto a special cartridge, then add some buffers, insert the cassette into the machine, and the machine does without further interference isolating RNA, RT and real-time PCR. After an hour, we have made as many samples as the apparatus performs $4,8,16$, i.e. a 16-station apparatus replaces at least 80 hours of hard work of diagnosticians, it is suitable for use in the professional testing laboratory SARS-Cov-2 at the airport [27, 60,]. Roche equipment offers better equipment in the form of a cobas 8800 camera, providing 96 results in 8 hours [27, 28 ,

The only way to escape from a total crisis is to enter innovative technologies, new materials, new measuring instruments, computer and ICT identification of human contacts in 5G technology, which is already working in China, even on the street, in the form of drones with cameras monitoring fever in 200 people at the same time. Only such a development of technology and adaptation to closing borders, limiting uncontrolled globalization will allow return to flying again. If we can do 11 million tests in 10 days, it is enough to adopt the testing model used in May in Wuhan. After examining 6.5 million people, only 200 infections were detected, which is nothing. There is no SARS-CoV-2 virus in Wuhan! I estimate that $80 \%$ of the world's production of tests and personal protective equipment is made by China and Korea.

\section{Introducing innovations to passenger control in the time of COVID-19 as a way out of the crisis of aircraft and airline manufacturers.}


The introduction of innovations in passenger control during and after COVID-19 is used to implement international transport in such a way as not to transport infected people with overt symptoms, as well as even asymptomatic patients from one country to another. The advanced system for diagnosing SARS-CoV-2 virus and COVID-19 disease is an instant running distance, disease detection, testing and system tracking contacts of the sick or suspected person with other people. An integrated IT and telecommunications system coupled with GPS, databases is the basis for effective tracking of contacts of infected persons with and without symptoms, with other persons and their identification. All activities related to diagnosing a patient and his contacts by means of a location system should be limited to the necessary activities of the carrier, who is not obliged to replace the tasks of the state $[13$, 14 ,

56].

The introduction of innovations should include an integrated flight management system designated COVID-19, which integrates the following elements with each other:

\section{- Organizational system for preparing passengers for the flight}

The organizational system of preparing the composition of passengers including: passenger health card for COVID-19 disease, prepared on the basis of a survey containing the written consent of the passenger, for making available; his personal data, your health data, access to COVID-19 medical examinations. The passenger's consent also applies to tracking his contacts and the persons he has contacted, using digital tools including telephones, geolocation using GPS to the extent necessary to secure the health of passengers. Data collected during organizational work will be placed on the server for use on return flights or subsequent flights. In the future, an interactive application will be developed, charged from the flight organizer's website, which will allow the passenger to prepare the required data for the online survey. Only necessary information is collected.

The implemented integrated control system for the mobility of citizens should be organized at the level of a given country, but in most countries it does not exist, hence aircraft manufacturers and airlines together need to start building such a system, relieving of governments based on obtained in writing the consent of passengers to provide conditional sharing of their private data. Such an integrated system of citizens' mobility control covering telephones, GPS, health cards, biometric data, healthcare databases and passengers allows to fight the SARSCoV-2 virus increases the safety of passengers in the COVID-19 range. Of course, the mobility control system will be implemented to the extent possible, because the purpose is only to prepare the composition of passengers. Such a system is implemented practically in China, South Korea and Taiwan, is thoroughly described and can be used in your company. An integrated information technology called in Korea "smart city" has been developed in Korea, which uses information technology and cellular network technology together with GPS together with software to track people's position, search people, inform and warn of the threat to other residents. Monitoring citizens' mobile phones using a special application with a GPS system allows the history of locations infected with GOVID-19 to be viewed on a publicly available map. The country's authorities collect data from payment cards, city monitoring, and medical interviews with patients. Only such integrated databases allow you to effectively track a suspected or ill person with COVID-19 and people who have been in contact with her in the last 14 days. The idea "smart city" as time-space cartographer in COVID-19 control: the South Korean strategy and democratic control of surveillance technology were described by J.W. Sonn, K. Lee [30, 14, 4,].

\section{- Preparation of stands for taking swabs for tests and performing PCR tests}

Preparation of stands for taking swabs for tests and performing PCR test for persons who must have such tests. The passenger may carry out the test earlier with the knowledge and consent of the flight organizer. Stands for the rapid collection of swabs, their practical organization, efficient, organized at airports as separate stands have been discussed along with the examples in the previous section. This solution allows you to download materials for testing on site, quickly, without the need for disinfection and waiting time. How to choose test methods for swab samples, what automatic devices to use for this, what PCR and rapid serological tests to use, when what problems to choose for practical solution, because innovative devices and tests appear all the time and a very optimal selection should be made due to price, time of completion and reliability of the measurement all these decision must be made after careful market analysis. When purchasing tests, they should be bought with a written guarantee of their confirmed effectiveness, which the manufacturer provides in the form of a written guarantee and on-site measurement service if there are problems with the tests $[20,26,61,62]$.

\section{- Taking passengers temperature measurements, fever measurement, other ordered measurements}

Taking passengers temperature measurements, fever measurement, other ordered measurements given in the survey before boarding the aircraft, during the flight and seating passengers in places according to the virus optimization system. Laser thermometers for single measurements have the disadvantage that they are distanced $10-20 \mathrm{~cm}$ from the head and the measurement lasts $2-5$ seconds, i.e. the measuring person must be in full suit. Thermal imaging cameras for measuring the simultaneous body temperature, more precisely the state of fever for up to 30 people simultaneously from a large distance of 1-9 m, i.e. they can be portable, for use on board the aircraft and at the airport, in the transition to sleeves, etc. These cameras measure head temperature with an accuracy of $0.3^{\circ} \mathrm{C}$, have the ability to search 30 people in the image, identify faces, check the mask on, inform passengers, and voice alert staff about the person's infection. There are several types of thermal imaging cameras from Hikvision and others. There are thermal imaging cameras for measurements of up to 200 people simultaneously and in China they are installed on drones. Measurement of temperature and fever does not apply to people with COVID-19 in an asymptomatic manner and they constitute $80 \%$ of all patients! [30, 51,53 ,

$57]$.

AI Rokid glasses can check at a distance whether someone has a fever. In two minutes, the Chinese can measure the temperature even for several hundred people. Thus, temperature and fever measurements are solved using the presented innovative measuring instruments [31]. However, we still have no way to 
measure and detect asymptomatic patients. It cannot be excluded that measurements of body temperature and other parameters of arriving and departing passengers will become a new element of air travel around the world. New airports in Asia, such as BeijingDaxing Airport, are already equipped with thermal imaging gates that automate and speed up the check-in process [53].

\section{-Ways of obtaining substitute passenger spacing instead of actual requirements using personal protective equipment and other innovative methods.}

Replacement spacing has been developed using personal protective equipment and other innovative methods.

Passenger spacing, i.e. keeping the actual distance on an aircraft between two passengers, sitting in rows or columns, is not possible on the plane. This distance, according to various teams of researchers that I analyzed, should be even; $7-8 \mathrm{~m}, 4.5 \mathrm{~m}, 2 \mathrm{~m}$, does WHO give at least $1 \mathrm{~m}$. Research in the USA is supported by the registration of cough outbreak experimentally [23, 24, 25]. According to Chinese cameras confirmed by cameras, the virus traveled on the bus over a distance of $4.5 \mathrm{~m}$, remained suspended in the air for over 30 minutes and infected 7 people [58]. Secure other passengers so that this required distance is $10-20 \mathrm{~cm}$ and meets safety requirements. If for example, between two passengers we will set a sealed wall in the form of a plexiglass plate from ceiling to floor, we will reduce the distance to the thickness of the plate. Therefore, with a fixed distance between passengers, the actual distance is $10-20 \mathrm{~cm}$ and it should be increased theoretically by the optimal selection of personal protective equipment and other methods. It is not possible to change the aircraft deck into a honeycomb, which is why I suggest using several other solutions at the same time, which will allow to reduce the distance required to $10-20 \mathrm{~cm}$, without fencing or reconstruction of the deck. The measures taken must ensure safety in terms of COVID-19 for all passengers and staff [23, 24, 25]. As it results from Fig. 1, it is possible to safely take a swab from a patient, but the protection measures shown are not enough there, because it takes place in a special extraction chamber with fans, which is not visible in the photo and it was described in detail in the previous point and this is related to ventilation and air $\begin{array}{llll}\text { conditioning in aircraft } & \text { 20]. }\end{array}$ We can carry out spacing on the plane with; accessories for the protection of the respiratory tract, protecting lips, nose and eyes, with the help of accessories, protective clothing and design solutions in the form of seat covers, cassettes tilted on the back joint, and air conditioning and ventilation solutions. Spacers with personal protection accessories include HEPA, FFP3 face masks, covers or plastic visors covering the face and eyes, google glasses, hair hats, disposable gloves, disinfected wipes soaked in disinfectant, waste bags, liquid for disinfection we in this way we isolate the passenger from the passenger. Protective clothing used separately for each passenger is; full protective suit, disposable or reusable. This protective clothing should be light, ventilated and aesthetic, e.g. from special materials such as medical fleece, which are permeable to air, steam, and not to let in viruses, bacteria, dust or dust. I give the name of the non-woven of fleece material, but this term should be understood as any type of material used for sewing protective clothing for medical services working in infectious hospitals with patients. You should choose innovative materials commercially available with, attestations that protect against viruses. Non-woven fabric of fleece is used in the form of several layers for masks. Construction methods include; assembly of a transparent plastic cover, tilted back, placing partitions between seats, construction of covers in passages on board to protect excessive air turbulence and drafts. Aviointeriors designed transparent covers mounted on economy class seats that create a barrier at the height of passengers' faces. Structural elements should be used in moderation, because they also do not guarantee $100 \%$ safety, so they can wait for simpler measures to fail [21, 32 , 35 ,

54].

In South Korea passengers at Incheon Airport wear full lightweight protective suits, look like interlining, and wear full coveralls used in infectious hospitals by medical personnel [34]. Protective clothing should be loose enough to read, drink from a bottle and eat ready-made sandwiches. All protective clothing, personal protection accessories, disinfectant materials must be provided by the organizer and uniform for everyone [21, 35].

In my experience, and I have been working with aerosols in the laboratory for several dozen years, simplifying protective clothing for the mask will not work. It is impossible to achieve tightness of such a $100 \%$ amateur mask, i.e. it is a cheap, easily accessible but uncertain protective measure. The IATA air traffic organization claims that the controlled ventilation system of the aircraft promotes the creation of vertical chimneys of air migration, which should impede virus infection by neighbours. This can also support the required distance of $2 \mathrm{~m}$, which on the plane must be brought using personal protective equipment to 10 $20 \mathrm{~cm}$. The actual spacing in large stores, in open spaces, to be completely safe should be from 4-8 $\mathrm{m}$, because fine particles of aerosol travel over large distances, smallpox virus up to $50 \mathrm{~m}$. On the other hand, air exhaust filters on decks should be equipped with filters type HEPA and the filter cartridge should be disinfected or replaced after each flight.

Personal protection equipment has been provided to passengers in the form of overalls and masks, using innovative materials of filter cloths can be very convenient to use and safe. The same innovative masks are already on the market, with carbon fiber inserts that will better meet the conditions of virus filtration than FFP3 and HEPA and will have low flow resistance. Remember to protect your eyes. In the field of masks, these innovative tools have been developed [33]. Professor Eckard Nagel who managed the German-Chinese hospital in Wuhan during the epidemic of the virus crown in that city made five main conclusions from his work in China. In turn, they are: 1 . Consistent and quick response, then 14 days after a radical reduction of social and economic life, the number of new infections begins to decrease, but the intersection of infection chains requires twice as much time. 2. Medical personnel can work only 6 hours a day, because then the number of infections and deaths decreases. 3. Concentration of patients for treatment in selected infectious hospitals. 4. The need for mass testing. The patient is released from the hospital only if he has two negative tests within three days and after release the patient still needs 14 days of quarantine and should be monitored electronically. 5 . Introduction of the obligation to wear a mask for everyone in public places. Masks are a key means to prevent new infections [34]. Professor Gao Director-General Chinese Center for Disease Control said in an interview with Science that; "Everyone who leaves the house must wear masks," and "Those infected with 
coronavirus, even if they have no symptoms, should be isolated." Masks are not intended to protect those who wear them in public. They are to protect others from potential infected SARS-CoV-2. The biggest mistake that the US and Europe make is that people in the public area do not wear masks. Whenever a person says if they are breathing, small droplets appear outside the body [34, 35, 54].

\section{- Appropriate selection of passenger and other supportive restrictions}

The masks should be chosen very carefully, because we have several dozen types of masks for painting, welding, atmosphere and poison vapors, anti-smog masks and surgical masks. The mask should protect the person who wears it from being infected with SARS-CoV-2 virus even if the person next to her will cough, sneeze, throw a drop spray or simply breathe. The mask should also protect other people next to us in the event that we are infected with a virus and sow it around us. So the mask has two protective functions, it protects us against infection from other sick people and protects us against infection from me. Masks used for protection against the SARS-CoV-2 virus, particle diameter 60$140 \mathrm{~nm}$, should be selected so that they do not let the virus particles in any direction but they must be tightly fitted to the face and cannot be touched by hands. Masks are mechanical methods of influenza prophylaxis, therefore they are generally less effective than vaccinations. HEPA filters are the common name for the material, which is used in ventilation systems and devices such as vacuum cleaners, retain particles larger than $10 \mathrm{~nm}$, i.e. fungal cells, bacteria, protozoa and many viruses. Only some masks meet the HEPA standard, marked as Type Ir, Type IIR, FFP3, FFP2 (US equivalent N95), FFP1. Reusable FFP3 doublesided masks should be chosen because they retain viruses, bacteria and fungi according to the instructions. Many people undergo crown infection with no symptoms, which means they should be treated as sick and wear face masks, but they don't, because they don't even know about their illness. The selection of masks for aircraft passengers should be carefully selected FFP3 and tested before use. An OHS expert tells you how to choose and properly use a face mask to protect yourself from the crown with a virus $[32$,

33 ,

35.54].

\section{- Upon arrival at the destination airport, staff participates in passenger health control together with the airport staff}

Upon arrival at the destination airport, staff participates in passenger health control together with the airport staff, in the case of persons verified as healthy on COVID-19 they go to the airport check-in. On arrival at the airport, passengers suspected of being infected with COVID-19 are transferred to quarantine and hospital treatment if required and take care of the services of the destination country. Aircraft staff attend the airport's passenger reception and provide information necessary for treatment and quarantine, and help passengers with organizational matters such as payments, insurance, and deportees.

Most countries block their borders for patients suffering from COVID-19. "Dragged" by planes from abroad. For every passenger who has successfully passed all the control procedures before boarding the aircraft, the onset of illness only during the flight and at the destination airport will be a surprise because he faces a large increase in costs, associated with a quarantine of 14 days or the cost of treatment in a foreign country. Most countries that have mastered the virus prohibit entry who, if they refuse quarantine, are immediately deported. If they agree to a 14-day quarantine, in closed hotels, in single rooms, they pay for the hotel and maintenance themselves, while their treatment depends on the destination country. Therefore, the transport organizer will offer the passenger already in the survey in exchange for voluntary consent to; disclosure and use of his personal data, medical data, blood test results, his cooperation in the field of COVID-19, placing his health card and survey on the server, providing telephone data to track passenger contacts with other persons over the last 14 days, geolocation, GPS, location of wanted people, it will be offered cheap insurance of these events or even covering part of these passenger costs. The problem of contact tracking may only become apparent at the destination airport, hence the flight organizer should have passenger data regarding COVID-19. Close cooperation between the air services of both countries of departure and arrival is needed. Return flights are carried out using the same procedures. Air transport has contributed to the mass spread of COVID-19 disease worldwide. Now the same airlines will help countries to maintain and eliminate the state of emergency of this disease.

My proposal is precisely to this can be done, that by increasing the administrative work of staff in the organization of flights, better instrumentation of airports, instrumentation of planes, optimization of passenger distribution on board, introduction of methods for innovative passenger measurement, introduction of techniques for tracking control contacts electronic people infected, control the outbreak of the disease or keep a suspicious passenger on board the aircraft.

\section{- Measuring instruments and innovative devices for use} with COVID-19.

Aircraft manufacturers and airlines must look for innovative measuring instrument solutions that are useful for rapid deployment to passenger air transport, and a significant number are already on the market or at the testing stage, and other problem solutions should be directed to research teams to develop. The article discusses most of the available innovative apparatus useful for diagnosing passengers.

However, we will discuss a few more innovations to apply. For example, AI Rokid glasses detect people at risk of coronavirus if they have a fever. The Chinese startup Rokid has developed glasses that use thermal imaging technology to check if someone has a fever from a distance of up to 1 meter. The equipment is used by guards at the recently opened Hongyuan Park in Hangzhou. Thanks to the device, it was possible to reduce the waiting time to enter, because according to the South China Morning Post it can measure the temperature of even several hundred people in two minutes. If the glasses register someone with a high fever, the staff is automatically notified and the face recognition system saves the person's biometrics in their database. The disadvantage of technology is that it does not detect cases in the early stages of the disease or those with no symptoms [31]. The group of innovative devices also includes pulse oximeters for measuring saturation, blood oxygenation and pulse measurement, because they are additional measuring instruments. Dr. Richard Levitan, a respiratory specialist at Bellevue Hospital in NY, said that with a pulse oximeter and thermometer, Americans can be 
diagnosed and treated for COVID-19 before they develop severe symptoms. All people with cough and fever should monitor their health with a pulse oximeter, even if they have not been tested for coronavirus. Levitan focuses on monitoring the level of blood oxygenation using a pulse oximeter. The device is attached to the finger and after a few moments you receive information about the level of oxygen saturation. The normal value is between 95-98 percent. For people over 70, the norm is considered to be between 94 and 98 percent. The pulse oximeter works by measuring the absorption of red blood cells in the capillaries with radiation of two different lengths. The signal measured by the pulse oximeter consists of two components: constant and variable (pulsating). The variable component describes the absorbance of pulsating arterial blood. Based on the measurement, the oxygen saturation ( $\mathrm{SpO} 2)$ is calculated. The pulse oximeter may also be able to measure your heart rate. A pulse oximeter test is also performed on patients to counteract respiratory failure. This is important, especially when monitoring the patient's condition during general anesthesia, during oxygen therapy and in the event of a patient's severe condition

At the airport in Hong Kong, the CLeanTech cab has been built, whose task is to fully disinfect passengers. The device, which looks like a telephone booth, is being tested. According to a message issued by the airport, the system used in the booth is able to remove all impurities from the skin and clothes. Cleaning takes 40 seconds and uses a disinfectant spray - reports Business Insider [37]

Urgent is needed developing new measuring instruments for nonelectric quantities using electrical and computer methods.

\section{- Modernization of the existing on-board entertainment installation and adaptation to new tasks of cooperation with the Internet, databases on the server and with passengers in 5G technology.}

The airlines have recently given up due to costs and license fees for the use of in-flight movie display with on-board entertainment systems, which will take the passenger during a long flight. Entertainment costs per chair are large and amount to approx. 35 thousand. PLN (7900 Euro) for one flight seat. In addition, throwing monitors reduces the weight of the aircraft, which reduces fuel costs. I propose to thoroughly modernize the existing entertainment installation in such a way as to adapt it to support the increasing organizational tasks facing airlines in connection with COVID-19 and the economic crisis. I propose to change the entertainment system into a system of individual internet service for each passenger separately. Each passenger has full high-level internet service and support for airline databases, ticket sales system, database system, kept on airline servers or in the cloud. The passenger should be supported and kept thoroughly informed as they do in Taiwan and Korea in the form of press conferences to eliminate stress, fears, distrust of the passenger and that he is not surprised by the lack of complete information. The system can be used, first of all, to inform passengers about new transport rules, rules of conduct during a flight, during a stay in a foreign country, including the possibility of browsing the database, booking flights, etc. The system can be used to deliberately prepare professional training related to with COVID19 flights, which a passenger can also download from the company's server before booking a flight, which will significantly shorten the continuous repetition of the same content for each passenger separately by company and airport personnel. Possibilities of developing such an Internet system for passenger service, education, and viewing nature films in free forms. For example, even websites provide thousands of magazines, books in free writing and in the form of audio-books. The system will also limit the use of the smartphone during the flight, which will improve safety, because the same can be done using the on-board system. Playing music from youtube will probably be possible without fees? The system will allow subsequent modernizations of the flight management system, which is its most important function. A wisely organized on-board entertainment system will allow you to inform, deliver press, music from YouTube, educate and gain customer trust. The system should also be used to communicate with Skype using a flight passenger. The possibilities of using such an existing system, which only needs to be modernized, are limitless, even to read newspapers in electronic form, analyzing maps of the area where we are going or describing the country where we are going [64, 65] .

- New rules for the reception and service of foreign passengers at airports in China and countries that have mastered the pandemic by innovative methods.

It was possible to completely close the borders for air, road, rail and sea traffic, but for a short period, e.g. a month, until methods of extinguishing and suppressing a pandemic were developed. Further blocking is to the detriment of countries and nations, because we are pushing ourselves into recession and a long-standing crisis. Generating such an industry, trade, services, education blockade causes, huge unimaginable economic losses that are impossible to make up, e.g. one day of Lufthansa aircraft parking is a loss of EUR 1 million. At present, China has completely overcome the epidemic and the only problem is the virus "dragged" by airplanes from Europe and the USA. The Chinese government is aware of the dangers of receiving people from abroad, hence new provisions have been introduced to regulate international arrivals of passengers from abroad. Therefore, from March 23, 2020, a new restrictive directive came into force, regarding all foreign arrivals to the Chinese capital of Beijing. Planes that were directed to Beijing are first directed to 12 other cities, called "the first place of arrival". Thus, all passengers on foreign flights who land in one of the twelve cities are directed to sanitary inspection and baggage collection at a given intermediate airport. If they pass the check, they are allowed to continue their journey to Beijing. All who arrive must undergo an inspection, and if there is a suspicion that they may be carriers of the coronavirus, they are directed to a 14day forced quarantine at the hotel at their own expense in the intermediate city. The bus transports passengers from the intermediate airport to the hotel, you can choose the type of hotel. In the marriage hotel, families are separated, because everyone has a single room, no way out, and food is delivered to the room. . After quarantine and after checking with a medical test that you are definitely not a carrier of the virus, you can return to your permanent residence in the city. There remains phone contact with other people. People who have passed the sanitary inspection from the intermediate city are flying to Beijing, where only the inspection is carried out to check whether the person is at risk and not a medical test confirming the state of health. It is not known 
for how long this condition will last, but it must be stated that the responsibility for the condition of passengers is borne by aircraft manufacturers and airlines that organize flights. In the case of quarantine, the cost of flight for a passenger and the desirability of arriving increases significantly, since he was going to a 3-day conference and ended up in a 14-day his flight quarantine [52, 53, 1,2 , 11 ,

$51]$.

Taiwan had only 300 infected people by February 31, 2020, same to Vietnam. Taiwan certainly deserves first place on the epidemiological podium. Although located less than 150 kilometers from mainland China, and the flow of people between countries is very intense, by the end of March on the 24-million island of coronavirus infected only 300 people. Epidemiologists point out that, just like in Vietnam, security checks have already begun on December 31. A "command center" for communication with citizens was also rapidly established. Interestingly, the authorities' reflexes prevented the coronavirus from spreading, leaving schools closed for only two weeks. Epidemic Command Center

$[13$,

15].

- First signs of reviving domestic air traffic in China and other Asian countries after COVID-19

It is necessary to carry out very precise preparatory work to launch such transports using the Airbus 380 -860, because you have to reckon with a dynamic change in the decisions of Asian countries, which adapt very intelligently to the changing situation. Countries that have overcome their illness with great effort and resources, do not want to let it come back, hence the stringent rules introduced during the pandemic still apply. In the first place, I am considering the destination country for large passenger aircraft China, because it is a market three times larger than the entire EU and five times larger than the US, which is crucial for large aircraft manufacturers and large airlines. The article, based on literature research, discusses how aircraft manufacturers and airlines are to prepare themselves to deal effectively with the problem. Based on these literature studies, the largest aircraft have the greatest chance of resuming flights, as the unit costs of organizing the flight and the costs of passenger service increase significantly. Secondly, the restoration of priority priority aircraft, i.e. the most economical ones for aviation for mass transport before a pandemic, e.g. Airbus 320neo and Boeing 737 MAX, which can already be restored to flights in countries with large areas, i.e. the USA, Canada, should be considered China, Australia, Brazil, Russia. In these countries, you can start domestic flights after introducing and checking personal protective equipment to limit the spread of this virus. China is already implementing flights to China based on the solutions provided in the article, which should be adapted to the tasks of aircraft and airline manufacturers. China has successfully mastered the pandemic and will immediately develop the restoration of air transport because it performs most of the transport of medical supplies in the world. China has a handicap in the form of ending a pandemic, as Europe and the US are still struggling with a pandemic. It should be remembered that the loss of a year may change the situation on the market of competitiveness of air passenger transport. The Chinese company COMAC launches the production of the competitive Comac C919 aircraft, which is to be a competitor for the Airbus 320neo and Boeing 737 MAX. For now, orders have been placed by 3 Chinese airlines, an American investment company, but Ryanair is also trying. The time it takes for practical solutions that work out can be critical [41,42,

The article has the form of a guide with a list of tasks and problems to solve and gives information on how to solve a given problem at the current stage based on the state of the art of scientists and experience in the field of measuring apparatus. The proposed solutions concern how the distance between two people from $2 \mathrm{~m}$ can be shortened to $10-20 \mathrm{~cm}$ by means of passenger's personal protection and flight organization. Next, it was discussed what preparations, tests and measurements should be carried out, before the flight, during the flight and after arrival at the destination port. It also discusses the handling and handling of passengers to minimize COVID-19, just before flight, during the flight itself, and how to deal with infected people. The work concerns the preparation of aircraft for transporting people during the COVID19 pandemic, but the procedures and procedures also apply to diseases caused by other viruses. If airlines want to return to regular flights as soon as possible, they must restore passenger confidence and reduce the risk of COVID19 infection. The first forms of state aid should be to help airlines organize domestic internal flights in order to restore passenger confidence and test new COVID-19 news and innovations.

The first domestic test flights can take place with the participation as passengers, voluntarily selected persons from flying personnel, flight attendants, airport staff, to test subsequent solutions with the participation of several infected persons and the press and media. The adopted innovative solutions must still be presented and accepted by the governments of countries where real transport will be carried out. This is even more urgent because in recent days China has strongly tightened restrictions on people arriving in China, with an emphasis on foreigners. Further countries are already adopting Chinese procedures and they will become the norm $\quad[1,2, \quad 34, \quad 49, \quad 53]$

6. A practical guide to the task of preparing aircraft for international flights, step by step in the days of COVID-19.

Those subsections of this chapter and the entire article, which have already been positively resolved in the given two countries, are omitted, if do not we consider them to the needs, because the guide is written for each country in the world. My proposal is to restore to flight and to resume production of the magnificent, in my opinion, Airbus 380, in comes in two versions 550 and 850 people in economy class. It is a pity that this plane does not fly and there are no further orders for it. In this calamity that airlines encountered, a 90\% drop in flights is ruin and bankruptcy for airlines. For Airbus 380 this misfortune can be a chance, a light in the tunnel, for a slow, slow return to flying. Since a return to the previous state from before the epidemic is unlikely, effective adaptation of one type of aircraft to times of crisis will allow the slow modernization of the entire industry. This study is most useful for direct practical application for longrange wide-body aircraft, A380 section 8.1 x $7.15 \mathrm{~m}$, or Boening 747 section $7.81 \times 6.5 \mathrm{~m}$. Large hull section and two decks with a large surface allows it to better adapt to flying in COVID-19 times. In my opinion, the larger the fuselage diameter, the better it is suitable for transporting people infected with COVID-19, asymptomatic infected people and healthy potential candidates for infection. Currently, transporting people by air exposes them to 
virus infection and COVID-19 disease. There is a simple non-investment method to verify my idea of "Airbus 380 for COVID-19". It is enough to test several economical version 850 planes without any changes on routes to China and other countries. China is also vitally interested in restoring air transport on the China-rest of the world route, and we will need their experience and assistance to further modernize this aircraft to transport people potentially infected with COVID-19. The company Airbus sees the first signs of a revival of the aviation industry in China, the more that it has production facilities in Tianjin producing Airbus aircraft that have briefly stopped production but have already resumed it. General Director Guillaume Faury said on March 23 this year that he saw the first signs of a return to normality in the context of domestic air travel, which with the market of 1.4 billion people is probably not surprising [7]. That is why I propose that air traffic restoration should be started from large national markets and from countries that have lifted the restrictions on crossing borders. Boeing has also decided to build the first terminal equipment line outside the United States, not accidentally in China. The plant will be located in Zhoushan, China and will ultimately produce 100 Boeings 737 a year, in a version most likely MAX [40,42]. All passengers embarking must be potentially treated as infected with COVID-19, despite being healthy despite having no symptoms of illness, despite having no symptoms temperatures, they must be safely transported to the destination port, without contact with another person. At the destination port, they again need to be checked, if there are patients who were revealed only during the flight, they will be referred to hospitals, if they have no symptoms for quarantine in a closed hotel facility, at the beginning, unfortunately, for two weeks and then they will be delivered to the places where they arrived. Perhaps the SARSCoV-2 virus will disappear by itself, just like the previous virus with the same name SARS has disappeared. In my opinion, this is very unlikely, because governments are ineffective or have ignored the threats and the pandemic has spread to more countries. On April 1, 2020, there should be no SARS-CoV-2 pandemic in any European Union country, only individual cases! Hardly any government has used pandemic suppression methods implemented successfully by states; China 60 million people in blockade, Taiwan 25 million, Hong Kong 7 million, South Korea 52 million, Japan 126 million, Singapore 8 million I conducted quite thorough literature research on COVID-19 disease. I know exactly the methods of infection and the course of the disease from the moment of infection to the end of the disease, recovery, day by day, hour by hour. I know exactly the procedures used by China when transporting people from Europe to work in China after having mastered a pandemic, this is a very difficult organizational issue and you need to adapt to it in air transport, otherwise China and other countries will withdraw passengers from the airport back to the plane.

The first promotional flights, e.g. for $50 \%$ of the price, or as you suggest there, you can do to test this idea without investment. The Airbus 380 has 11 rows of seats on two decks. The sale of tickets and their price would have to depend on the variant that you, as a company, accept for use. I only consider large planes, because in my opinion they have the best chances of survival on the market. Nothing stands in the way to then implement similar procedures for all types of Airbus aircraft.
The basic problems and tasks facing the flight organizer that need to be solved step by step to achieve the intended goal.

\subsection{Passenger health card, survey, database and recommendation for COVID-19}

Establishment of a database for passengers for a given flight "Airbus 380 for COVID-19" containing a boarding pass with a simplified passenger health record prepared on the basis of a prepared survey. The passenger at the stage of ordering the ticket downloads a survey and description of additional conditions. The survey contains justification and a request for his consent to voluntarily disclose his personal data, his telephone number, his telephone contacts, his SMS, e-mail and health data of state services (hospitals, clinics, laboratories) only for the purposes of the COVID-19 pandemic. The simplified health record for the purposes of COVID-19 will be used only for its treatment or for establishing all contacts with infected persons, or who may have infected it, which took place in the last 14 days before the day of flight. The questionnaire in the form of a health record must be prepared in such a way as to allow all passenger contacts and identification of persons with whom he has been contacted so that they can be quickly identified and examined. The survey must be prepared professionally, according to the order of validity of the information provided. If the passenger suffered from COVID-19, he encloses a photocopy of his test results or enter the end dates. The passenger survey is initially verified at the ticket ordering stage and the form is prepared for electronic processing. Different countries have different rules sharing personal data, e.g. GDPR in the EU, so it is recommended to obtain the written consent of the passenger to share his personal data and data regarding his telephone contacts, e-mail and health data. The organizational problem can be solved at the EU level, which will lift the ban on disclosing personal and computer and telephone data for the purpose of the COVID-19. No one will carry out the tasks listed in the study, producers and airlines must do it to launch safe airplane

flights.

Admittedly, some countries have already joined the debate on such a health card, but how much can you debate and wait? The EU recommends voluntary use of tracking applications, but does not agree to track infected contacts. According to Deutsche Welle from March 10, 2020, the European Commission has no proposal for tracking applications, however, downloading such an application is to be voluntary and the EC does not agree to the geolocation of infected. So producers and airlines have to count on each other. Philippe De Backer, the telecommunications Belgian Minister explained, "We don't need that. We are able and traditional to look for people who have contact with the infected.

" The Belgian authorities announced the employment of two thousand additional people to find contacts called (Epidemic "detectives") by the traditional method [55]. It follows that aircraft manufacturers and airlines can only count on themselves. According to the Korean Ministry of Infrastructure and Transport, "smart city" techniques can reduce the time it takes to track a person's movement from one day to about ten minutes [4]. National governments introduce regulations allowing the location of their stay, which is allowed by the smartphone technologies [56]. 
If there were difficulties in saving surveys, sickness cards on the servers of aircraft and airline manufacturers, due to the GDPR, you can try to save this data on passengers' smartphones, but there will be a problem as the passenger does not have a telephone or his telephone is of the old type. This data collected on airline servers will be available on the next journeys, while stored on the passenger's phone will be useless.

6.2. Passenger's written consent to share his personal date, his treatment date and voluntary participation in studies of infectious diseases COVID-19 and other.

Passenger's written consent to share phone data and consent to measurements, tests, tests, contact identification and treatment. The passenger at the stage of ordering a ticket in the survey is informed that if he falls ill with COVID-19 before the day of departure, he will inform the airline about canceling the flight and then he will not incur any costs in this respect. If the passenger, when measuring the temperature before boarding, has a temperature or if the test result is positive, he will not be allowed on board The passenger consents to temperature measurements, fever camera measurements and others, before the flight, during the flight itself and at the destination airport. I also agree to perform tests and measurements at the airport in the destination country. If the test is positive and if it turns out that the passenger fell ill during the flight, he will agree to receive hospital treatment or a 2 -week quarantine in the destination country and will cover the necessary costs himself. The flight organizer will provide him with the necessary assistance in this respect appropriate to the legal conditions at the moment. To this end, it is worth considering cheap insurance to cover research and quarantined hotel in the destination country. The problem of 2 -week quarantine, perhaps, will solve itself after the positive implementation of several flights to China and obtaining permission, both countries operating the flight, to replace it in another form, which will be proposed in appropriate time [55,56].

\section{3. Optimization of passengers distribution on board due to COVID-19.}

The aircraft is fully disinfected, HEPA air-conditioning filters are replaced and is prepared for flight. All passengers are treated as potentially infected with the virus, although they are healthy, even though they have already suffered from COVID-19 and even if they have a certificate that they were ill. The principle of very limited trust should always be applied to this virus. All seats on the plane are taken and sold, if possible. No empty rows of armchairs! The sale begins with the sale of odd-numbered seats, and when they are full, we sell even-numbered seats or vice versa. There are some possibilities here for optimal control of seats in the aircraft, depending on the composition of passengers and susceptibility to COVID-19 disease. Passengers over 60 years of age, especially those suffering from other civilization diseases, should be seated in extreme places in rows, because they are most susceptible to getting sick. People with several diseases affecting the body are treated as those most at risk of infection. As published by the Italian Institute of Health, COVID-19 has many more 58\% men suffering and dying than $42 \%$ women. This is confirmed by data from Lombardy, which indicates that $82 \%$ of patients in the intensive care unit were men, with deceased men representing $78 \%$ of patients. Also other studies to date show that men suffer from this disease more often than women [48]. That is why men should be seated between women whenever possible. In contrast, children under 18 can be seated to separate adults among themselves. At a later stage, we will develop a computer application that automatically reads the data from the survey and allocates optimally seats on the plane. I emphasize that the optimization of proper bursting of passengers is of fundamental importance for the epidemiological status of the entire composition of passengers and crew.

\subsection{Temperature measurements, fever and passenger tests for COVID-19.}

Every passenger must have their temperature measured with a laser thermometer before they get on the plane and take their place. Such measurement raises the possibility of an infected measuring person. This temperature measurement also doesn't give us much, because it is only the first indicator, nothing more. A thermal imaging camera should also be used to measure passenger fever. An infrared camera can be installed at the airport during the transition to the sleeve with the plane. However, this allows us to conclude that the passenger did not have overt symptoms as he boarded the plane, because his two measurements were taken. COVID-19 disease has an incubation time of even 1 to 21 days in extreme cases. During a 10-12 hour flight, should be measured the temperature of all passengers every 2 or 3 hours to catch passengers who have already discovered COVID-19 disease during the flight itself and need to be immediately transplanted into a separate room for infected people, so that they do not infect other passengers from the side, back and front. During the flight, it will be better to measure the temperature of passengers with a portable thermal imaging camera that simultaneously measures up to 30 people. It is already known from the literature how I determined that infection is dependent on the number of SARSCoV-2 viruses infected and the time of exposure to the virus. Approximately 5 places should be prepared in single, separated areas on an airplane for patients whose disease will only become apparent during the flight. It would be advisable for the crew to have a pulmonologist or trained nurse on board who could connect the respirator to the breathing. One ventilator should be easy to use in order not to land on the road. The Airbus 380 has 860 seats, which is almost as many people as on 16 buses. The service at the destination airport is carried out by the services of the given country together with the aircraft personnel who have printed the distribution of seats, who sat where and has all passengers' boarding passes on the laptop. Upon arrival at the destination airport, you must measure the temperature again. This data made available to the epidemiological control services of the destination airport will significantly speed up the flight check-in. We suspect passengers suspected of being infected at the airport from the rest and carry out their tests, including tests, and if we carry out the procedures described above correctly, there will be few or none at all. The decision as to which passengers still make the services of a given country and the aircraft crew must adapt to this. We load quarantine passengers to the bus and take them to a collective quarantine hotel, where service is taken over by the destination country in accordance with the provisions in force there. Passenger service is taken over by the airport and destination country, which makes sure that the plague is not let into your country. Passengers whose temperature has been measured stay in quarantine for 2

This publication is licensed under Creative Commons Attribution CC BY

http://dx.doi.org/10.29322/IJSRP.10.07.2020.p10326

WWW.ijsrp.org 
weeks (in China they pay for the hotel themselves) or to the hospital for recovery, and after recovery and 2 negative tests are released. Temperature measurement and tests cause that we also catch people suffering from traditional seasonal flu and other viral diseases manifested by high body temperature, e.g. HIV, Ebola, SARS-CoV-1, MERS and a number of others and even colds, but they are not the subject of of this guide, they must be handled in accordance with the medical knowledge and law of the country in which the passengers are. There is never $100 \%$ certainty that individual people with no symptoms or people who do not give the truth in the survey will be on the plane but the controlled optimization reduces the possibility of falling ill. Optimization of passenger seating can also take into account other scientifically proven features of the virus. For example, a person suspected of being infected may be asked to indicate the smell of the perfume, because according to research in the United Kingdom, about $80 \%$ lose smell and taste. Because there is little experimental research in the literature in this area, while most information is checked, at least in 3 sources, as in this article $[57,53,51,50]$.

\section{5. Personal protection measures to distance passengers and cabin crew.}

Passengers at the departure airport receive personal protective equipment for the flight upon boarding. These are aprons from materials impermeable to viruses, in the form of suits appropriately selected, commercially available, a mask one or two, 3-5 wipes soaked in hand disinfectant liquid, 3 pairs of gloves, a plastic bag closed with waste. Caution should be exercised when drinking, eating and using the toilet. Passengers do not have any hand luggage, and drinking and eating is served on the plane. Protect your personal protective clothing so that you cannot touch your face, nose or eyes. At the Lodz University of Technology, fabrics have been developed that are permeable to air and water vapor, and not to allow viruses. If there are manufacturers of overalls from such certified materials that are impermeable to viruses, then they should be tested and ordered. Strict personal protection measures are necessary at the initial stage of launching COVID-19 flights in order not to burn the project. Even if the funds given are redundant, they can be gradually modified and the unnecessary ones be given up in turn.

In the second stage, it is necessary to consider replacing the suit with a mask with a plastic visor with a mask, but first it must be checked experimentally in the plane and with the visualization of the flow of air streams, because IATA claims that the air conditioning of the aircraft produces a vertical draft, which reduces the chance of infection [34, 22, 38.39].

Cabin crew should begin to be secured in the way that doctors are secured in infectious hospitals and gradually, step by step, eliminate the outfit of protective clothing, starting from the shoes towards the head, until only the head, neck and possibly part of the body from the height of the bust up. If the virus tests show that it is impossible to get infected through the skin, then a protective suit in addition to the head and upper torso is unnecessary. It is recommended to avoid designing outfits in white because it is associated with the hospital. According to the publication of photos from Bild 9.06.2020, the airlines have already started designing and using protective clothing.

As it results from the publication of photos and Bild's article of 9.06.2020 showing the protective suits of flight attendants of several airlines; Philipine Airlines, Thai Airways, Gulf Air, Air Asia and European airlines. Air Asia has the most stringent protective clothing, such as medical service in infectious hospitals. Until the end of the year, this line offers promotional prices of tickets within Asia at prices of 3-5 \$ one way, it is a pity that hotel prices are not promotional, which I checked. The same article "Masks and coveralls" in Bild was repeated on 11/06/2020 [67, 68] Asian countries had MERS, SARS-CoV-1 and now SARS$\mathrm{CoV}-2$, so that fear and panic are not unreasonable there. It is a pity that the same rules have not been adopted in the EU and the US, for which we are paying a very high price. You can start by copying the costumes of these airlines to the beginning, but there is one catch hidden in this proposal - a question mark. In Italy, as many as 163 doctors and 37 nurses or nurses died during the pandemic on COVID-19, by $12 / 05 / 2020$. According to the published opinion of the doctor prof. from Italy (I forgot my name but I have it) one of the reasons for so many deaths of medical personnel is the infection of people while taking off their infected suits. A doctor in full protective suit is not entitled to be infected with a virus. Putting on the suit is simple but taking it off, contrary to appearances, when it is infected, is an extremely difficult and dangerous operation. Special courses are run in hospitals for personnel in removing the infected suit. Therefore, in my opinion, full hospital overalls will not work on the plane (in addition, in the pictures in Bild you can not see the whole outfit) and at the first contact with the virus, flight attendants will get COVID-19. I remind you that a large increase in mortality was also noted, even in gravediggers, during the outbreak of a mass pandemic in Lombardy.

On the other hand, conducting on-board courses for employees in putting on and taking off infected full medical suits is pointless. In the event of infection, the employee must know what to do, subject to PCR and 14-day quarantine. Therefore, other solutions to this problem need to be sought [70]. The suits shown in the pictures in the Bild newspaper can be modeled, but only if they are not full medical suits, because special sanitary regulations must be applied to them. Other elements of the protective suit are acceptable [68,69].

Aircraft personnel should have regular molecular and serological or both tests as described above for their safety and passengers. One collective test can be performed for the entire crew, e.g. for 10 people using the so-called technique of pooling genetic material but it must be a reliable good laboratory [26]. Unfortunately, most of the recommendations used in research and recommendations on how to behave people in the presence of coronavirus were unfortunately wrong, this also applies to WHO and most governments. There is a whole series of news from the research of scientists that we did not know about.

Chinese scientists verified information on the most common coronavirus transmission in May. The fastest way to get infected is by breathing and talking, while the droplet pathway through coughing, sneezing, or a spray from the mouth, also causes infection, but to a lesser extent than we thought. Instead, the role of infection by touch, which was over-preferred, decreased. Masks helped stop the spread of a pandemic, say researchers, but only to whoever wore them. They inform that patients with COVID-19 breathing, secreting even a million viruses per hour. Earlier it was thought that coronavirus spreads fastest through coughing and sneezing. Just as I mentioned, the spray from the 
mouth can be 7-8 m away. Now it is known that rapid transmission of the virus is conducive to breathing and speaking. "It would explain why it spread so easily all over the world," writes Dailymail [66] . Earlier studies previously discussed from the USA were confirmed [23, 24].

There are at least a dozen health ministers, members of the government, who said that wearing masks is unnecessary and even harmful. I have been using masks in my laboratories for several dozen years. Studies have shown that the consistent wearing of masks will prevent the second wave of this virus pandemic [71]. Chinese scientists from Sun Yat-sen University, who have already submitted their findings for publication in Gastroenterology, have thoroughly examined 73 patients with confirmed SARS-CoV-2 coronavirus infection. Blood, nasopharyngeal swab, urine and stool samples were collected from all. Tests for SARS-CoV-2 in faeces were performed by RT-PCR. I do not discuss the research results in detail, they are in the given article, but they are shocking. The presence of the virus in faeces, urine and in samples of collected organs was confirmed; esophagus, stomach, duodenum, rectum. According to experts, the risk of infection also increases the use of public toilets [70 ]. In addition to lung damage, the virus penetrates the brain, heart, kidneys, male testicles and the effects it causes are huge and this also applies to asymptomatic diseases. Faecal and urine infections are also possible with the help of faeces and urine trapped in the air [ 70 ].Therefore, for employees, we can take a throat swab, blood, urine, faeces for periodic tests. Sewage tests for this virus are already being carried out, e.g. from Spain, i.e. by examining sewage from separate airport buildings, we can approximately determine where people were infected with the virus [ 72 ]. Therefore, I propose to periodically examine samples of sewage from the aircraft for the presence of a virus to confirm the health of passengers and crew. Toilets for the crew should be separate. The method of testing sewage is suitable for searching groups of employees, groups of passengers where there were people infected with the virus. Tested sewage from the toilet from the plane at the airport in Beijing, will allow you to quickly verify whether our aircraft is clean from the SARS-CoV-2 virus, with a very high probability, efficiently and cheaply. The database on the company's server and crew computers on the plane, perhaps even at the destination port, find sources of infection.

\section{Innovative methods for testing SARS-CoV-2 virus and COVID-19 \\ disease.}

The first group of innovative methods are modern tests to study the presence of this virus in the human body, as discussed in the article. These are devices that automatically perform several hundred RT-PCR tests per day, new technologies that shorten PCR tests to several minutes and dozens of tests developed and implemented for mass population testing. An interesting method is pooling swabs for a group of people in one study, if we suspect that everyone is negative. Other innovative methods should also be sought.

\section{Examination of wastewater from the toilet and in sewage canals.}

It belongs to innovative and cheap method include wastewater testing. We already know that faeces, urine are the source of infection and the entire digestive tract is the habitat of the virus and it should be expected that body fluids, i.e. blood and lymph, will also actively participate in the spread of infections throughout the human body. Using a method of testing the presence of the virus in wastewater, we can track entire groups of people, including those most difficult to detect, in asymptomatic patients, in several studies. Wastewater research conducted in Spain was used to assess whether the virus is already present in the main sewage collectors of Barcelona, and to determine the starting places, the so-called zero patients with outbreaks of infection in the this disease [74]. Sewage epidemiology (wastwater-based epidemiology) is one of the cheaper methods of diagnosing and searching for patients, while it does not cause infections alone [75].

However, research shows that the virus in the sewage system can, however, help to localize the outbreaks of the disease and asymptomatic carriers. Every person infected with SARS-CoV-2 discharges millions (if not billions) of genomes of the virus into the sewage per day. This translates to from 0.15 to 141.5 million viral genomes for every letter of waste water generated. Outside the human body, the virus quickly ceases to be dangerous, although fragments of its RNA still remain, enabling its identification. Nowhere was the virus found in drinking water, as provided by US CDC (Centers for Disease Control and Prevention) [76, 77].

Scientists from several centers; Arizona State University, the Australian University of Queensland and British Cranfield University see in these studies a chance for easier detection of virus outbreaks thanks to sewage epidemiology (WBE). It is therefore possible to determine how many infected people, including asymptomatic carriers, are in a given area. It is only necessary to investigate which aircraft the collected sewage comes from [77, 78 ]. One should return to the already proven methods of testing sewage for the presence of hepatitis A viruses and polio. This method can be used only in countries where there are efficient sewage systems and it is only $27 \%$ of the world's population, or 2.1 billion people. It is estimated that the sewage method accounts for only $1 \%$ of the cost of tests, although the tests cannot be completely eliminated [78 ].The proposed method is simple, cheap, effective and easy to use in aviation as one of the methods of virus diagnosis. In some cases it perfectly complements tests and other methods. You can use it in apartment and do it yourself with indicator tests. Unfortunately, most of the recommendations uses in research and recommendations were unfortunately erroneous, including those of WHO and most governments, There is a whole series of news from research scientists that we did not know.

\subsubsection{Proposed bans and restrictions.}

A total ban on carrying hand luggage on board an aircraft and even newspapers, books, a computer, laptop or tablet. It is particularly important to emphasize the prohibition of touching the face and restricting conversations between passengers, the use of common items and everything that is discussed in this guide as conductive restrictions. Passengers are not allowed to bring their own food, sandwiches, sweets, peanuts or drinking on board. I suggest that you completely give up food for passengers, while passengers receive bottled and foiled mineral water. Passengers get a set of protective measures in the form of handkerchiefs impregnated with a disinfectant liquid for washing hands, a trash bag, disinfectant gel in a tiny sachet, 5 pieces of paper towel. The 
neighbors can communicate with each other, on board the plane and with the family on the ground, e.g. friends and family members using the modernized Skype form, the on-board entertainment system. Members of the same family will also sit in different places of the plane, as the purchasing system will seat them tickets.

The problem of newspapers and books should be solved by means of an on-board entertainment system and its modernization. Contracts should be signed for the supply of cheap press in electronic form, on such promotional terms as the Berlin Morgen Post does in the field of sharing entire articles on COVID-19. Similarly, the editors of other even scientific journals, such as Lancet. Scientific publishers like Elsevier, Springer provide only selected articles for free, just like JATM, but you can negotiate with them to extend the free offer for airline passengers, this can be collectively negotiated with IATA. $5 \mathrm{G}$ network is just entering, i.e. streaming possibilities will increase several hundred times, i.e. this network should be entered into the on-board entertainment system. The on-board entertainment system should allow for recalling cabin crew when needed and ordering a queue for the toilet, as there will be no additional toilet cubicles on the decks. It is recommended to recommend passengers maximum use of the on-board entertainment system and limiting calls from their own mobile phones. In this way, we avoid speaking that strengthens viral

infections.

A total ban on smoking cigarettes, including electronic cigarettes, should apply to all facilities: aircraft, airport, commercial and service facilities related to the airport. Cigarette smoke enhances the transmission of the virus in the air over long distances. Ladies should be asked not to overuse fragrances.

\subsection{Masks, overalls and other protective elements for passengers and cabin crew.}

The mask is supposed to protect us against the virus in closed rooms, because the virus travels in the air for long distances, it can also attach to small liquid droplets or dust particles and all aerosols with diameters below $10 \mu \mathrm{m}$ can be transported in the air over long distances. For example, the smallpox virus can travel in the air over a distance of over $50 \mathrm{~m}$. The virus transport is also supported by ventilation and air conditioning systems in market halls, airplanes. For now there is no research in airplanes about how small droplet aerosols will move. It is known from my research that the distribution of aerosol droplets in clouds is similar to the distribution in dust clouds of low concentration, i.e. close to normal distribution. For this mask to fulfill its role, it must have a double-sided HEPA filter, which is the standard for masks marked FF2, FFP3. Masks marked with the N95 standard are approved by WHO, but popular surgical masks do not meet these conditions. The mask should preferably be reusable, it cannot pass SARSCoV-2 viruses with a diameter of 40-140 $\mathrm{nm}$ in any direction and it must be air and water vapor permeable, while it must not cause significant difficulty in breathing. Masks with excessive flow resistance that make breathing difficult are harmful. It must be remembered that separate masks are used for running, cycling, walking, etc. Our mask is to stop the virus particles in both directions and this must be recorded in its operating instructions. The selection of passenger masks should be made taking into account the composition of the air supplied by the air conditioning.
Popular masks available in the market, in my opinion, are completely unsuitable for protecting passengers on aircraft from viruses. If necessary, we will take care of these masks in next paper $\quad[21, \quad 23, \quad 32, \quad 33, \quad 35, \quad 54]$.

\section{7. A protective cap with an elastic band, covering all hair.}

Human hair is most susceptible to electrostatic charging in the air. Therefore, the hair is very electrified, which makes it a reservoir; dust, dust, organic particles in the form of viruses, bacteria and fungi. Tests on the electrification of human hair and their impact on very fine dust particles were performed in my laboratory and recorded with the Schliernaufnahmegerat-80 apparatus [38, 39]. The hair is closest to the human holes susceptible to infection; lips, nose, eyes and ears. In this situation, viruses flowing in the air are caught and attach to the hair. From the hair they get into the nose, mouth, eyes and become infected. Using a mask is completely pointless if you do not have a permanently hair secured protective by means cap or headgear. Both men and women in particular must have their hair tied up in a bun and tucked completely into a protective cap made of nonstatic fabric. There is no research in the literature on the electrification of human hair and its impact on the increase in virus infection, in this case SARS-CoV-2. In my opinion, a very significant percentage of infections will result from hair infections. To a lesser extent, this applies to beards, mustaches and hair all over the human body. We conduct thorough research for several months literature and my own in the laboratory, I have never met a description of the role of hair in human infection with SARS-CoV-2 virus [32, 34, 38, 39].

\subsection{Other methods of distance passengers during the flight.}

There are still several solutions to be implemented later. These include transparent plastic covers proposed by Italy, mounted on the seat articulation, tilted back, about $60 \mathrm{~cm}$ high, but they must obtain safety approvals. Such covers are used by the Taiwanese authorities in primary schools just to increase the distance between children but are placed on the tables. Such shields for students used are in China and South Korea, Taiwan refer to this. They should be combined with a mask and visor and then slowly try to opt out of plastic visors. Such covers must be tested with the participation of heated mannequins in order to determine air flow streams, whether they meet safety standards [38, 39, 22, 23, 24].

It was published in the press that several airlines are considering the possibility of flights with $50 \%$ seat filling in order to distance passengers. The $50 \%$ version without individual protection measures for each passenger, in my opinion, will not work. Such a problem has already arisen before, allergic infections in planes, because it was forbidden to eat peanuts on the plane, because the consumer infected two rows forward and backward, and two rows from its sides. The infected person was given life threatening anaphylactic shock. Alternative solutions that can be easily used later, in my opinion, for the Airbus 380 aircraft version 860 , there are, in my opinion, at least a dozen or so, require aerodynamic tests, but considering them at this stage is pointless, because you need to look for low-cost solutions. It is not possible to achieve a distance of 1-2 meters from the passenger on the plane. IATA and the president of Rynair were very harsh against leaving the vacancies [42, 43, 49, 53]. 


\section{9. Benefits and disadvantages of performing RT PCR and rapid serological tests for all passengers just before boarding.}

It should be emphasized that performing even very accurate molecular PCR or serological tests at the airport before flight is completely pointless, because this virus is extremely intelligent and contagious and can be detected only on specific days after infection and we do not know in how many days it stop infecting, since its extreme infection periods are 1-50 days. This virus can survive in the freezer for up to 2 years, on objects for up to 17 days. In Europe, there are countries where even more than 50 molecular PCR tests performed for employees of the same hospital were false, because both molecular (genetic) PCR tests and serological (immunological) tests were false positive and negative [26]. Such situations are possible when existing diagnostic laboratories have poor diagnostics, or different tests from different manufacturers are used. Diagnostic laboratories for PCR tests must be with experienced diagnostic staff, while rapid serological tests never give $100 \%$ certainty of the result, but we can easily repeat them many times, because there are already 10 and 2 minute tests. PCR and blood tests are completely separate tests and their purpose is different. You have to understand the essence of the SARS-CoV-2 RNA virus and its method of very malicious infection, because PCR measurement is performed only for a given moment of time when the swab is taken, and this virus behaves completely differently the next day from the day of infection. At the same time, the state of infection and disease COVID-19 depends on the patient's state of health. In aviation, only PCT automatic test devices are considered, e.g. from Roche, 860 tests in 3 hours and similar $[27,28,29,60,61]$.

Test attempts for all aircraft passengers have already been done on Emirates, but they cannot, in my opinion, give satisfactory results, as they do not take into account the ability to infect and survive this pathogen. However, just doing the tests is a move in the right direction because it reduces the number of infected.

The rules of very limited trust should be applied to all tests. By their very nature, blood serological tests are much less reliable. Before purchasing, serological tests should be verified in consultation with the seller, who should give a certificate of correctness, as they are sometimes poorly performed and companies claim that they are ineffective and have been deceived by the supplier $[60, \quad 61, \quad 62]$.

\subsection{Search for other methods of searching for people with asymptomatic COVID-19.}

The situation may improve when a second and further reliable methods or instruments are developed for quickly measuring the state of infection of infected people suffering from asymptomatic diseases, which they themselves do not even know. We need measuring instruments to diagnose people with no symptoms and no such instruments. Asymptomatic people do not have a high temperature, do not have a fever, may not have any other symptoms, but all the time at the same time, they can infect other people without even knowing it. Expensive PCR tests cannot be performed for all passengers, and they also do not give 100\% certainty, because they give positive results but only on strictly defined days from the date of infection. Teams of research laboratories consisting of medical scientists and physical and technical sciences have to look for new instruments and cheaper measuring techniques. I will give an example; the dog has a 600 times better sense of smell than a human and can be, it is one of the hopes, trained to verify passengers infected with SARS-CoV2 virus at the airport. Works in this area are carried out in Great Britain. In my opinion, such measuring instruments can be pulse oximeters for measuring non-invasive monitoring of blood oxygen saturation percentage (saturation) and heart rate, but this method still requires experimental research and verification. Are needed a quick measurement with non-invasive instruments based on measurements of non-electrical quantities using electrical methods. Also laser technology and fluorescent methods suggest that such measuring instruments will be developed. We fight with an invisible, very tiny enemy with a diameter of 40-140 nm, about which we know practically nothing, because our experience is limited to observing various bad effects of his action [36, 49, 51].

HEPA filter for the aircraft. The aircraft should have one collective HEPA filter whose cartridge is a cassette, easily replaceable. After each flight or after several flights, this filter should be tested for COVID-19 virus content after removal. I know this is quite troublesome because you need an electron microscope, the pathogen particles are 40-160 nm. On this basis, it is possible to assess whether we transported the sick and for which contagious diseases. Based on the amount of virus on the filter, you can estimate how many people were sick. I do not know the construction of the aircraft ventilation and air conditioning system, but if the decks are served by several HEPA filters, it is possible to estimate where the infected passengers sat. This method is to assess whether the transport system used is epidemiologically safe.

\section{Increasing the availability of toilet cabins and sinks on board during the COVID-19 era.}

It is also a problem to use the bathroom during the flight to use the toilet and wash basin. It would be best if one bathroom was for $50-80$ passengers, so that the passenger does not make long trips on the board of plane. After using the bathroom, the cabin must be automatically disinfected after each use. You can set several toilet cabins on each deck separately, for now portable, and then life will verify how to solve this problem to make it optimal. Because each passenger will use the bathroom and the toilet about 4 times during a flight of 10-12 hours, the bathrooms must handle about 3400

entries.

For the passenger, sitting still for 10-12 hours in an armchair, additionally dressed in a tight impervious suit is a significant difficulty, hence other solutions may be considered in the

future.

\section{The advantage of wide-body aircraft of the Airbus 380 , Boeing 747 type, for transport during the COVID-19}

The biggest disadvantage of the Airbus 380 was that it is too large, now this large surface becomes its advantage, because it can be used to distance passengers. Airbus 380 planes are probably also designed for cargo transportation, because here the lifting capacity is decisive, because its packaging capacity is high. Don't hurry up the reconstruction of ready made Airbus 380 aircraft, because the problem may disappear by itself when the pandemic disappears or other methods for simple control of asymptomatic 
passengers with infected passengers are developed, e.g. using trained dogs, the emergence of new measuring instruments outside of temperature measurement. The idea is not to incur the costs of modernizing the aircraft, which may prove unnecessary in 3 months. You need to start your first flights and watch the situation very carefully and quickly adapt to changing regulations and the state of the pandemic. The situation on the oil market has changed, it is not known at what level the price of a barrel of Brent oil will stabilize, but its price of around $\$ 30$ means that the importance of the price of fuel drops significantly. A 4-engine plane is safer for the customer, although its servicing and operation are more expensive

$[42$,

49 ,

$51]$.

\section{Ports hubs in the days of COVID-19.}

In the case of transport using intermediate airports as hubs, this is how the Emirates line worked, the plane lands at a given hub hub, passengers remain on the plane in their seats or they are released from the aircraft to a separate area of the airport, separated from the rest of the airport while maintaining distance 1- $2 \mathrm{~m}$. There they can use bars, restaurants, take a walk, read the press and after a break they are loaded onto the plane. If new passengers are loaded from this hub then it is implemented and the aircraft continues to the destination. During their stay at this airport, they keep a distance of 1-2 $\mathrm{m}$ from each other. However, hubs are losing importance with the Airbus A380 and Boening 747 flight ranges, the more so as fixed costs of services in ports will increase significantly and the number of flights will have to be reduced $[49,62]$. Hub ports are needed to fill the aircraft with passengers to improve the economics of airline service.

\section{Identification of other viral diseases and COVID-19 flights after the invention of the vaccine.}

Development of a vaccine against SARS-CoV-2 may solve the problem but it does not have to be at all and it will be only in a year or two, later or not at all. 20 years have passed and there is no vaccine for HIV, MERS, SARS-1, so that announcements of the development of an effective vaccine and its implementation are two separate problems. One passenger infected with COVID19 can infect half a plane, and he does not even know that he is a virus carrier and infects, it is difficult to even punish him. If the aircraft manufacturer can ensure that the plane is filled with people who are not infected with the SAR-CoV-2 virus and who have not been infected asymptomatically and can prove it, then it has an open path for safe flights to any country in the world. Already at present, flights on the "Airbus 380 for COVID-19" are possible to around 10 countries of the world. Since China is currently ahead of most highly developed countries in the field of computerization, telephony and practical computerization (such as 5G technology), we need to copy their methods used in China as well as possible, we must learn from the better. When it comes to $5 \mathrm{G}$ technologies, the leading countries are; South Korea, China, USA, Estonia, Finland, Switzerland, Great Britain and Italy [40, 41, 49].

\section{Passenger flights awaiting $\mathrm{SARS}-\mathrm{CoV}-2$ vaccine.}

It should be taken into account that the SARS-CoV-2 pandemic will not be controlled in all countries even within 2-3 years. It will be possible to fly to some countries almost completely safely, e.g. to China, Taiwan, Hong Kong, Singapore, Japan and other expensive procedures will have to be used. It should be remembered that planes prepared in this way can safely transport people infected with other viruses, e.g. HIV, SARSCoV-1, MERS, Dengue, etc. The list of these diseases caused by viruses is over 20. The worst is that even if we had mastered the SARS virus -CoV-2 causing COVID-19 throughout the world, in all countries, which is unlikely to happen, in 3 months, a year or two, the mutated virus will appear even more contagious and we are having fun again. The SARS-CoV-2 virus is already the third coronovirus in this group that caused epidemics in 2003 and 2010. According to Iceland researchers, there are already 40 minor mutations of this SARS-CoV-2 virus. This SARS-CoV-2 virus has already been discovered in a much more contagious form than the one raging in Wuhan. I would like to point out that the COVID-19 vaccine, as developed, will be able to be used, but only for healthy people, because it is probably not for infected people. For people who have suffered from COVID-19 overt and asymptomatic, it will be necessary to test antibodies to this virus, as is done for vaccinating hepatitis B. At present, no one tests COVID-19 antibody levels, and if these antibodies are unstable, the problem is that no vaccine can be produced. Its purposefulness is doubtful for people who have previously suffered from COVID-19, because scientists need to determine how many years the antibody protects the person from getting sick. It cannot be excluded that there will be further pandemics of similar or more contagious viruses $[12,26,34,35$, 59 ,

$60]$.

12. Use the recommendations of this guide to distance people staying in the following clusters; sports stadiums, entertainment halls, street manifestations, cinemas, theaters, parliament rooms, parliamentary rooms, lecture halls at universities. Direct use of the recommendations given in the organization of rail, bus, road transport for passenger transport and sea transport.

Adaptation of distance and safety methods for rail transport, in meters, buses, in parliaments, parliaments, theaters, cinemas and

stadiums.

The technical safety rules given in this article are almost identical, with only a few modifications to be applied, in every type of mass transport; by trains, metro, buses and car traffic. Procedures in relation to airplanes can be used to distribute people in other rooms with the structure and arrangement of seats in the form of large halls, when we want to increase safety in relation to the distance of people as well as to secure people in places of collective stay. This applies to parliaments, parliamentary halls, lecture halls, entertainment halls, sports halls, theaters, cinemas and stadiums. For example, a football stadium like Barcelona's Camp Nou needs to solve similar problems as Airbus 380 to fill with people. According to several scientists, a patient with COVID-19 may throw coughs, sneezes at a speed of $55-160 \mathrm{~km} /$ $\mathrm{h}$, at a distance of $7-8 \mathrm{~m}$, when subsequent rows arranged in Roman Coloseum technology [63].

A more difficult situation exists on large cruise ships, such as Daimond Princess, where with so many decks, cabin and corridor dimensions this is a much more difficult problem to solve. Adaptation of a large cruise ship to transport people during a pandemic is much more difficult than adaptation of such an Airbus 380 . 
13. Final conclusion and comments

The aircraft is the most dangerous means of transport during an epidemic and must therefore be subject to special, redundant control in terms of passenger safety. According to my research, one patient with COVID-19 who doesn't even know he is sick, a passenger or flight attendant can infect even most passengers, if he is so sick on the plane and he will infect the environment with viruses for several hours, because it is important the number of viruses it will release and the long exposure of passengers to infection. Recall according to "Dailymail", such a sick person can secrete up to a million viruses per hour and infect everyone around. Until now, it was thought that infection could occur only through coughing and sneezing, but now it is already known that rapid transmission promotes breathing and speaking. This would explain why this virus has spread so rapidly throughout the world $[66,77]$. It follows that it is necessary to rigorously protect the head of the passenger and the service, of course, provided that the virus can not penetrate the human skin, which is $100 \%$ so far, we do not know it either. All WHO recommendations, most governments are not worth a pound of trouble. Two people can safely talk to each other outdoors at a distance of 7-8 $\mathrm{m}$ from each other, but we can not provide such a distance in any apartment, store, premises. Unless there is thorough research in the laboratory regarding SARS-CoV-2 virus and COVID-19 disease, all protective measures should be taken to protect passengers against illness. The introduced replacement distance means also protect against other infectious diseases. Isolation of each passenger and crew member as if he were placed in a single $2 \mathrm{~m}$ high plastic pipe, together with his seat, completely isolated from all other passengers, which is technically impossible to implement but this theoretical distance model should be sought. I would like my recommendations to be aimed at implementing this theoretical model as much as possible. guide:

The most important tasks to be performed according to the 1. Treating every passenger as a suspected person due to COVID19

disease.

2. Introduction of passenger geolocation control by means of tracking his phone, connected to GPS, medical databases, airline database locating his place of stay and his contacts on the map for treatment, quarantine and flights. In many countries this problem has been solved at the government level, where not, you need to ask the passenger for permission and create these bases himself. 3. Performing pre-flight tests only in doubtful cases, the rest of the organizational work must be performed by the passenger in cooperation with the airline on the basis of a questionnaire and health

card.

4. The use of computer technique for selecting seats on the aircraft in accordance with the instructions of the guide. Performed measurements during the flight and isolating the patient immediately as soon as it reveals so that it does not infect further. 5. Selection of innovative measuring apparatus in accordance with the guide.

6. Selection of several methods of passenger protection and isolation in order to effectively distance and isolate them from neighbors.

7. Introduction of innovative methods for testing the presence of virus in aircraft wastewater and air conditioning filters. 8. Modernization of the on-board entertainment system in accordance with the guide's instructions and coupling it with passenger service databases and $5 \mathrm{G}$ internet. 9. Commissioning scientific research to develop new innovative head protection measures and testing the distribution of air streams in aircraft.

10. The implementation of the guide's recommendations by each reader for their own private health purposes.

\section{REFERENCES}

[1] https://www.o2.pl/informacje/powrot-koronawirusa-w-wuhan-zapadlawazna-decyzja-wladz-6509415748048513a

[2] https://www.o2.pl/informacje/koronawirus-wielka-mobilizacja-w-wuhandaja-sobie-10-dni-6510432903235713a

[3] https://businessinsider.com.pl/ wiadomosci/koronawirus-jak- Szybko-sierozprzestrzenia-przypadek-call-center-w-korei-pld/lpv777j

[4] https://wiadomosci.onet.pl/politico/koronawirus-korea-poludniowazwalczyla-wirusa-dzieki-znakomitej-organizacji-i/q9t3g17;

[5] https://wiadomosci.onet.pl/politico/koronawirus-korea-poludniowazwalczyla-wirusa-dzieki-znakomitej-organizacji-i/q9t3g17;

[6] https://wiadomosci.onet.pl/swiat/koronawirus-na-swiecie-pacjent-31-wkorei-poludniowej-sekta-ogniskiem-epidemii/yxjs $75 \mathrm{x}$;

[7] https://wiadomosci.onet.pl/swiat/koronawirus-nowa-normalnosc-wchinach-i-korei-po-przejsciu-pierwszej-fali-wirusa/z7w1xgn;

[8] Politico.eu

[9] https://www.rynek-lotniczy.pl/mobile/uziemione-b747-i-a380-beda-jakoiom-8291.html

[10] https://www.fly4free.pl/koronawirus-samoloty-i-lotniska-stana-sieszpitalami/

[11] https://turystyka.wp.pl/koronavirus-w-niemczech-jest-pomysl-abyprzeksztalcic-lotnisko-w-berlinie-w-superszpital-6496956020267137a

[12] https://plus.polskatimes.pl/wuhan-miasto-widmo-blokada-i-strach-przedzabojczych-wirusem/ar/c1-14753110 ; K. Sikorski. Polskatimes.pl

[13] https://trybun.org.pl/2020/04/03/jak-koronavirus-stal-sie-chinskimczarnobylem ; $\quad$; A. Turczyn. The Warsaw Institute Review 3 IV 2020

[14] https://www.rp.pl/Koronawirus-SARS-CoV-2/200409430-Po-76-dniachzakonczyla-sie-blokada-Wuhanu.html

[15] https://polskatimes.pl/koronavirus-chiny-epidemia-wraca-nowe-zakazeniaw-jilin-100-milionow-chinczykow-moze-czekac-powtorka-blokad-iLimiten/ar/c1-14978468

[16] https://www.medonet.pl/koronawirus/koronawirus-w-polsce, szwedzkiepidemiolog-krytycznie-o-lockdownie-i-zamknieciueuropy,artykul,13897204.html ;

[17] https://www.medonet.pl/koronawirus/koronawirus-w-europie,koronawirus-szwecja--anders-tegnell---glowny-epidemiologszwecji,artykul,06774431.html

[18] https://www.pism.pl/publikacje/_Zdrowie_i_polityka_Tajwan_w_walce_z _koronawirusem_; PISM

[19] https://wiadomosci.onet.pl/swiat/koronawirus-korea-poludniowa-zwalczylawirusa-dzieki-znakomitej-organizacji-i/0z3kk22;

[20] Politico.eu

[21] https://tvn24.pl/swiat/koronawirus-tajwan-krok-przed-epidemia-moze-bycwzorem-dla-swiata-4516801; Politico.eu

[22] https://zdrowie.radiozet.pl/Medycyna/Wiadomosci/Trzy-kraje-ktorezwyciesko-wyszly-z-pandemii

[23] https://businessinsider.com.pl/wiadomosci/koronawirus-w-koreipoludniowej-walka-z-epidemia/bw2fnv1

[24] https://www.theguardian.com/world/2020/mar/18/covid-19-south-koreanskeep-calm-and-carry-on-testing

[25] https://www.infodent24.pl/newsdentpost/koronawirus-167-podmiotowprzeprowadzac-bedzie-badania-drive-thru, 114773.html

[26] https://www.medonet.pl/koronawirus/koronawirus-w-polsce,pierwsze-wpolsce-mobilne-centrum-testowe-"walk-thru"--wymaz-pobiera-sie-odosoby--ktora-przyszla-pieszo,artykul,54316592.html 
[27] https://odpady.net.pl/2020/04/07/ekspert-koalicji-bhp-podpowiada-jakwybrac-i-wlasciwie-uzytkowac-maske-na-twarz-by-chronic-sie-przedkoronawirusem/

[28] https://www.medonet.pl/koronawirus/to-musisz-wiedziec,jakrozprzestrzenia-sie-koronawirus--ten-film-daje-domyslenia,artykul,95085178.html ;

[29] TV NHK Japonia

[30] L. Bououiba. "Turbulent Gas Clouds and Respiratory Pathogen Emissions Potential Implications for Reducing Transmission of COVID-19". JAMA. Published online March 26, 2020.

[31] C. Beans. "Fluid dynamics works hints at wheather spoken word can spread COVID-19". Journal Club. Highlighting publisdched papers selected by Academy members.

[32] https://www.medonet.pl/koronawirus/to-musisz-wiedziec,epidemiakoronawirusa--dystans-spoleczny-powinien-byc-jeszcze-wiekszy-badaczka-przekonuje--ze-dwa-metry-to-zbyt-malo,artykul,06939267.html

[33] https://www.medonet.pl/koronawirus/koronawirus-w-polsce,falszywewyniki-testow-na-koronawirusa-to-powazny-problem--rozmowa-zdoktorem-pawlem-grzesiowskim,artykul,75022873.html

[34] https://molekularnie.wordpress.com/2012/02/25/cepheid-genexpertanalizator-biochemiczny-do-real-time-pcru-hit-czy-kit/

[35] https://www.cepheid.com/?gclid=Cj0KCQjwwr32BRD4ARIsAAJNf_ 3roE2E8EfoO1fIjY1VaG9oWszrecpzXrX7Aza OrhvRbncjGFLPoIMaAvomEALw_wcB

[36] https://www.roche.com/media/releases/med-cor-2020-03-13.htm

[37] https://www.tandfonline.com/doi/full/10.1080/15387216.2020.1768423. J.W.Sonn, J.K.Lee." The smart city as time-space cartographer in COVID19 control:the South Korea strategy and democratic control of surveillance technology". J.Euroasian Geography and Economics. 9 May 2020.

[38] https://noizz.pl/design/okulary-rokid-wykrywaja-ludzi-z-ryzykiemkoronawirusa-uzywaja-ich-chinczycy/gh0nr6p

[39] https://ranking-oczyszczaczy.pl/poradnik-czystego-powietrza/jakie-maskiantysmogowe/

[40] https://odpady.net.pl/2020/04/07/ekspert-koalicji-bhp-podpowiada-jakwybrac-i-wlasciwie-uzytkowac-maske-na-twarz-by-chronic-sie-przedkoronawirusem/

[41] https://www.theguardian.com/world/2020/apr/03/south-korea-bars-entryforeign-nationals-refusing-self-isolate

[42] https://wyborcza.p1/7,75400,25832669,wszyscy-musza-nosic-maseczkizakazonych-koronawirusem-nawet.html?disableRedirects=true

[43] https://www.medonet.pl/koronawirus,pulsoksymetry-zyskuja-napopularnosci--wszystko-przez-slowa-amerykanskiegolekarza,artykul,90880064.html

[44] https://noizz.pl/nauka-i-technologia/na-lotnisku-w-hongkongu-stanelabudka-do-dezynfekcji-ktora-w-40-sekund-zabija-wirusy/7jsrghm

[45] R.Rojek, Z.Dudzicz. „Laboratorium elektrofiltracji i elektroseparacji Politechniki Opolskiej. AURA Ochrona Srodowiska. VII Konferencja n-t „Elektrofiltry 2004”. Dodatek do Aury nr 9/2004. „s.47-49

[46] Dudzicz Z. „Elektrofiltracja cząstek pyłu w polu wyładowania ulotowego zasilanego wysokim napięciem stałym i zmiennym. Praca habilitacyjna". ISBN 978-83-929195-0-6. Kraków 2009. S.1-176

[47] https://www.pasazer.com/news/43653/airbus, widzi,pierwsze,oznaki,ozywie nia,w,chinach.html

[48] https://www.komputerswiat.pl/artykuly/redakcyjne/comac-c919-chinskiodrzutowiec-ktory-ma-pokonac-airbusa-i-

boeinga/x24lvwjhttps://www.komputerswiat.pl/artykuly/redakcyjne/comacc919-chinski-odrzutowiec-ktory-ma-pokonac-airbusa-i-boeinga/x24lvwj

[49] https://businessinsider.com.pl/lifestyle/podroze/koronawirus-jak-zmieni-sielatanie-samolotami-podroz-po-pandemii-covid-19/wb7qghl

[50] https://businessinsider.com.pl/wiadomosci/ryanair-wznowi-loty-rozkladlotow-tanich-linii-lotniczych-od-1-lipca-2020/0jyfpd7

[51] https://www.o2.pl/informacje/koronawirus-wielka-mobilizacja-w-wuhandaja-sobie-10-dni-6510432903235713a

[52] https://www.youtube.com/watch?v=CRTcJNry87E

[53] https://www.youtube.com/watch?v=uRQ8qNDrxLg

[54] https://wiadomosci.radiozet.pl/Koronawirus/Polska-wsrod-rezimowwykorzystujacych-koronawirusa-do-represjonawania-obywateli
[55] https://www.medonet.pl/koronawirus-pytania-i-odpowiedzi/sars-cov-2,czykobiety-sa-bardziej-odporne-na-koronawirusa-,artykul,92702927.html

[56] https://businessinsider.com.pl/technologie/nowe-technologie/rewolucja-wlataniu-trendy-ktore-zmienia-przyszlosc-lotnisk-naswiecie/wr6xwp9?utm_source=recommend\&utm_medium = synergy\&utm_campaign = allonet_recommend_n_bi

[57] https://businessinsider.com.pl/sztuczna-inteligencja-w-walce-zpandemia/bjx 1dsp

[58] www.hikvision.com/europe

[59] https://www.medonet.pl/koronawirus/koronawirus-na-swiecie,co-robiachiny--aby-koronawirus-nie-pojawil-sie-u-nich-ponownie---korespondentmedonetu-,artykul,68916439.html

[60] https://businessinsider.com.pl/lifestyle/podroze/koronawirus-jak-zmieni-sielatanie-samolotami-podroz-po-pandemii-covid-19/wb7qghl

[61] https://www.medonet.pl/koronawirus/to-musisz-wiedziec,lekarka-apeluje-oddychajmy-przez-nos-,artykul,22935862.html

[62] https://www.euractiv.pl/section/polityka-wewnetrzna-ue/news/belgia-2-tysdetektywow-ma-sledzic-zakazenia-sars-cov-2/

[63] https://www.computerworld.pl/news/Jak-rzady-wykorzystuja-danelokalizacyjne-do-walki-z-koronawirusem,419878.html

[64] https://businessinsider.com.pl/termowizja-w-walce-z-covid-19/v1ymsyg

[65] https://wiadomosci.wp.pl/chinski-naukowiec-koronawirus-podrozuje-naodleglosc-45-m-noscie-maseczki-6487375819171969a 4,5 m i wisi w powietrzu $30 \mathrm{~min}$

[66] https://www.medonet.pl/koronawirus/koronawirus-na-swiecie,porownaniekoronawirusa-z-wuhan-i-sars,artykul,38011813.html 31 I 2020

[67] https://www,cepheid.com/Package Insert Files.Xpress-SARS-CoV-2/Xpert ; ( Vending machine manual PCR )

[68] https://www.asiatechdaily.com/genbody-coronavirus-test-kit/ Testy seto Korea

[69] www.koreabiomed.com/news/articleView.html?idxno=7953

[70] https://zdrowie.wprost.pl/zdrowie/10115390/dlaczego-nie-wolnopowstrzymywac-kichniecia-i-jak-zredukowac-rozprzestrzenianie-siewirusow.html

[71] https://www.fly4free.pl/rozrywka-w-samolocie/

[72] https://www.aviationheadlines.com

[73] https://wiadomosci.onet.pl/swiat/najczestsza-droga-zakazeniakoronawirusem-wcale-nie-przez-dotyk/nmv5bm8

[74] www.bild.de, Bild 9.06.2020. www.bild.de Bild 11.06.2020; Title of the article "Protective masks and suits".

[75] https://m.bild.de/reise/fluege/fluege/coronavirus-so-wollen-airlinesbesatzungen-und-passagiere-schuetzen-70931060.bildMobile.html

[76] https://www.tvp.info/48013235/koronawirus-we-wloszech-rosnie-liczbazgonow-wsrod-medykow

[77] https://www.mp.pl/ratownictwo/na-dyzurze/229925,koronawirus-abezpieczenstwo-personelu-medycznego

[78] https://wiadomosci.onet.pl/swiat/najczestsza-droga-zakazeniakoronawirusem-wcale-nie-przez-dotyk/nmv5bm8

[79] https://www.o2.pl/informacje/naukowcy-twierdza-ze-maseczki-ochronnemoga-zapobiec-kolejnej-fali-koronawirusa-

6520617469172448a?utm_medium=push\&utm_source=pushpushgo\&utm_ campaign $=02$-push

[80] https://pulsmedycyny.pl/czy-koronawirusem-sars-cov-2-mozna-sie-zarazicdroga-fekalno-oralna-985529

[81] https://www.medonet.pl/koronawirus/koronawirus-w-europie,koronawirusbyl-w-hiszpanii-duzo-wczesniej--niz-sadzono,artykul,39810217.html

[82] https://www.polityka.pl/tygodnikpolityka/nauka/1955484,1,na-tropie-sarscov-2-w-sciekach.read

[83] https://pulsmedycyny.pl/koronawirus-sars-cov-2-w-sciekach-nie-powodujezachorowan-ale-moze-pomoc-namierzyc-bezobjawowych-nosicielibadania-990039

[84] http://naukawpolsce.pap.pl/aktualnosci/news\%2C82063\%2Ckoronawirusw-sciekach-nie-powoduje-zachorowan-ale-pomaga-namierzyc

[85] https://www.polityka.pl/tygodnikpolityka/nauka/1955484,1,na-tropie-sarscov-2-w-sciekach.read 
[86] https://www.medonet.pl/koronawirus/koronawirus-na-swiecie,wirusa-dowielkiej-brytanii-przywiozlo-1300-osob--nie-bylo-pacjenta-zero,artykul,89508405.html

\section{AUTHORS}

First Author - Zygmunt Dudzicz. . Electrofiltration and Electroseparation Laboratory, Tarnowskie Góry, Poland I am a doctor of technical sciences, currently retired, I have my own private Innovation Laboratory in the field of Electrofiltration and Electroseparation. The laboratory deals with dusts, powders and aerosols in the field of air protection, environmental protection and health protection. I have my own scientific achievements in the form of JCR works published worldwide. In the years 2000-2011 it was a laboratory of the Opole University of Technology, implementing central research projects in Poland. In the years 2009-2018 I worked as an expert in innovative research at the National Center for Research and Development and financed by the EU. My profile is on the Catalog of Polish Science website www.opi.org.pl.

(C) Zygmunt Dudzicz

Tarnowskie Góry, 14 June 2020

Dr Zygmunt Dudzicz

Ul. Opolska 23/4

42-600 Tarnowskie Góry

Tel. +48 697619273

e-mail z.dudzicz@o2.pl 